\title{
ECONOMIC GROWTH AND THE INSTITUTIONAL TRANSITION OF THE REPUBLIC OF SERBIA
}

\author{
Edvard Jakopin* \\ Ministry of Economy, The Republic of Serbia
}

\begin{abstract}
Are the transitional countries of SEE trapped in institutional transition or not? The institutional transition that has been lasting for almost three decades, and almost two decades in the Republic of Serbia, initiated the rapid destruction of the institutions of the previous political and economic system, but the construction of new market institutions has been slow, inefficient and partial. The Republic of Serbia lost the three decades of economic growth and development, which, as evidenced by economic law, takes twice as much time to restore the system to the previous equilibrium of the length of the time which the system is located in off-balance. The average 3\% growth in the seventeen transition years is insufficient to compensate for the enormous backlog of the 1990s. The contribution of the research study to the work focuses on the analysis of the interdependence of economic growth and institution building. A special viewpoint is aimed at the corruption factor destroying institutions in all transition countries, reducing their economic growth and productivity, and negatively affecting the attractiveness of FDIs.
\end{abstract}

Keywords: economic growth, institutional transition, corruption

JEL Classification: 011, $\mathrm{O} 43$

\section{INTRODUCTION}

The unique phenomenon of institutional transition in the European transition countries has been existent for almost three decades and in the Republic of Serbia (RS) for seventeen years. Institutional transition in the Southeast European (SEE) countries began with the rapid destruction of institutions from the prior political and economic system, whereas the

* Correspondence to: E. Jakopin, Ministry of Economy, Vlajkoviceva 10, 11000 Belgrade, The Republic of Serbia; e-mail: edvard.jakopin@privreda.gov.rs construction of new market institutions was much slower and inefficient, with the different dynamics of construction from one country to another, depending on the speed of the implementation of the structural reforms and the European Union (EU) entry.

In particular, in the first decade of transition, only Estonia, Hungary and Poland, out of all the transition countries, built the institutions that would ensure the protection of property rights and the implementation of the regulatory reform of the business environment in order to stimulate investment. Despite the implementation of significant macroeconomic 
reforms, Lithuania and Slovakia failed for a long time to comply with the severe budget constraints on the subsidies to state-owned enterprises. A number of countries (Moldova, Russia, Ukraine) stuck in the socalled "reform trap", without the essential reforms ("the form instead of the reform"), because the previous system was recycled through the process of privatization and liberalization (Jakopin, 2017b, 106). In general, a number of the transition countries have managed to build a new institutional framework after the fall of socialism, but most transition countries are still trapped in institutional transition.

The transition economies predominantly relying on the resource, labor-intensive economic sectors were, as a rule, more suited to the elites that did not match the new institutional framework (the old nomenclature that benefited from the privatization or the newlybuilt group of company owners). The reasons for the very slow growth of market institutions in transition countries are that some authors look for previous great economic dependence upon natural resources and the historical experience of these countries during socialism (Bhattacharyya \& Hodler, 2010).

The subject of the research study is the institutional performance of the transition of RS, with a special research objective of analyzing the interdependence of economic growth and institutional transition in RS and the SEE transition countries, most of which are in the EU lobby.

The paper examines the hypothesis that without the development of stable institutions there are no sustainable high economic growth rates, and vice versa; that without the high rates of economic growth it is impossible to build stable institutions. Within this hypothesis, the effects of the global recession on institutional transition and economic growth were analyzed.

In this paper, the methods of analysis and synthesis, compilation and comparison were applied. The institutional transition analysis was based on the composite Worldwide Governance Indicators (WGI).

The paper is structured into two interconnected continents. The first explores the performance of transitional economic growth in RS; in the second, the research reorientation focuses on institutional transition, with a special emphasis on corruption analysis as the factor that affects the decommissioning of institutions.

\section{THE LOST THREE DECADES OF GROWTH}

The beginning of transformation in 2001 was welcomed by the RS economy, whose structure had been formed almost three decades before. After seventeen years, the short transition balance would be as follows: the slowdown of the 1990s, which is slowly (only three-quarters of the way now) reaching the lag in relation to the group of the most developed countries in Europe (EU-15) is not decreasing, but it is increasing in relation to the group of transition countries that were admitted to the EU in 2004 (EU$10)$.

Due to the economic distortions in the last decade of the last century, the sanctions and the NATO bombing, RS has lost three decades of economic growth and development, which confirms the economic legitimacy that it takes twice as much time to return the system to the previous equilibrium from the length of time in which the system was offbalance. Today, Serbia's economic growth is at the level of that in 1976, only amounting to $78.1 \%$ of the average of that of the GDP in 1990 (Figure 1). With an average rate of the annual growth rate of $4 \%$, it will take us other seven years to reach the level of 1990.

Serbia's industry has gone through a real transition tsunami; more than half a million workers less than in 1990 work in the Serbian industry today. Compared to 1990, the index of the physical volume of industrial production at the end of 2017 is twice lower (51\%), being at the same level as in 1972 .

The macroeconomic risks of the sustainability of economic growth in the entire SEE region are permanently present, with unemployment being the highest in Europe. The economic disparities between SEE and the EU are constantly at extreme boundaries. 


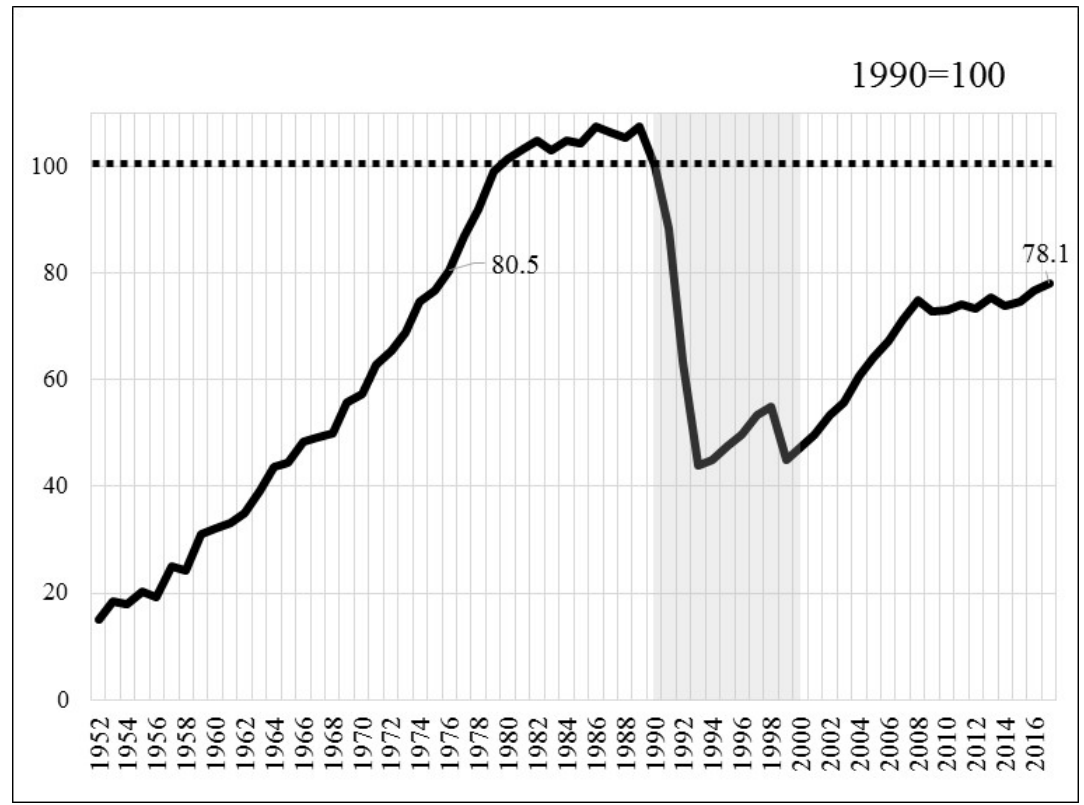

Figure 1 The lost three decades of growth - the Republic of Serbia GDP 1952-2017

Source: Author

Methodological note: Due to the changes in the methodology for the period 1952-2000, a series of trends in the social product (prices in 1994) was used, and in the period 2001-2017, a series of the growth rates of the GDP was used (Jakopin, 2018, 36).

According to all economic parameters, the SEE region belongs to the EU periphery. The living standard in SEE in 2016 was almost three times as low as the EU average, and the unemployment rate was three times as high. Regional and social cohesion in Europe is becoming weaker and weaker, and the SEE region is increasingly being confronted with the various forms of poverty and backwardness (Jakopin, 2017a, 157).

The SEE transition economies are slowly adapting to the globalization process, the ever-growing market competition, and the high demands coming from the competition. In the second half of the 1990s, the successful transitional economies had dynamic economic growth, primarily due to the growth of investments, personal consumption and the greater exports of goods and services. The initiator of their economic growth was the implemented structural reforms that led to significant changes in the structure of industrial production. The structural changes led by the postulate of greater international competitiveness caused an extremely dynamic growth of the industrial branches based on the use of modern technology and the economies of scale, the development of new industries, and creative economies.

The structural changes implemented through FDI inflows, industrial production and exports growth have contributed to the fact that the majority of the central European transition countries in and some SEE countries (EU Member States) have significantly increased their export performance, raising the entire industry of these countries to a higher level. The EU market has played the key role in the process of increasing exports. Innovative processes in science and technology in all the industrial branches are proceeding at a faster pace in the world, simultaneously bypassing the SEE region. 


\section{TRANSITION GROWTH MODELS}

The global recession created by a speculative price growth and the bursting of bubbles in 2007 opened many theoretical and practical dilemmas, beginning with the source of the crisis, the role of the state, market distortions, the systemic forms of the crisis, resource mobility, alternative solutions and growth models (Jakopin, 2018, 38-44).

Imbalances are deepened by the applied transformation model. The model functioned according to the principle of purchasing time with privatization revenues and FDI inflows, as the unstructured export-oriented economy borrowed and increased the external debt. On the other hand, the vulnerable internal stability conditioned by the huge surplus of imports over the exports and overstated the dinar that this huge foreign trade deficit has stimulated and sustained. The overpriced dinar carried the pillar of the anti-inflationary policy and influenced commodity flows, but due to cheap import raw materials and intermediate goods it affected production costs. In such a situation, the global recession only reduced oil to the fire.

A brief theoretical excursion about the causes of the global recession revealed that the causes of the hotbed of the greatest crisis since the Great Depression of 1929-1933 lie in the combination of the three factors:

- the enormous growth of the greediness (greed) of business entities (Keynes' famous "animal spirits"),

- economic policy failures, and

- the institutional framework (the regulatory system).

In recessionary periods, the state is more superior to the market, primarily because it has instruments to mobilize resources. For example, in all the variants of the state, the economic policy stimulates a faster development of entrepreneurship in order to reduce the "perception of risk". The crisis-trigger generator is always the system, not the state with its policy, because the economic system is inherently unstable. Through its instruments, the state creates structural reforms and changes the system so as to minimize losses. Some authors believe that neither the reconstruction of the system nor the transformation of the economic policy can eliminate the causes of the crisis. In a word, systemic instability is the key determinant of a recession. In addition to systemic causes, recession weights were intensified by the weaker export sector and the wrong economic policy, which manifested itself primarily through the strong domestic currency. Occasional catching was provided by privatization, FDIs and foreign borrowing (Jakopin, 2018, 42).

The basic characteristics of the pre-crisis transition model of economic growth in Serbia in the period 2001-2008. The years that had the greatest impact on economic growth can be described as follows:

- the process of the privatization of social property which was being turned into privately-owned was not followed by consistent institutional solutions, the effects were far less than expected;

- the growth of industrial unemployment was not accompanied by the growth of the entrepreneurial sector;

- the economic growth was based on the growth of services, not on the growth of industries exchangeable goods (industry, construction);

- consumption grew faster than economic growth, thus resulting in an increase in the external debt,

- the structural reforms in the economy were slow, selective and partial.

The average rate of economic growth in the transition period from 2001 to 2017 is modest, only $3.0 \%$. After the dynamic economic growth in the pre-crisis period 2001-2008 (the average growth rate was $5.9 \%)$, there came a fall in the crisis in $2009(-3.1 \%)$ and a long-term recession period (the average fall in the rate of economic growth in the period 2010-2014 was $-0,1 \%$ ), so that in the period 2015-2017 the mild signs of the recovery of economic growth followed (average growth was 1.8\%).

The transformation period 2001-2017 is characterized 
by different models of growth:

- The growth model based on the growth of private consumption and services in the period 2001-2008. In the period leading up to the outbreak of the World Economic Crisis, Serbia's economic growth achieved a high growth average rate $(5.9 \%)$, which, however, was not enough to compensate for the backlog of the sanctions against and the economic problems in the state at the end of the last century. The service sector was the main contributor to the growth model, with the services in the structure of the gross domestic product (GDP) reaching $60 \%$. In 2008, the level of the Serbian GDP reached the level of 1975.

- The recession period from 2009 to 2014 implies the years without growth, with the average annual fall of $-0.2 \%$. Under the impact of the global recession, economic growth was interrupted in 2009, and the economic policy makers were forced to redesign the growth model and face new growth sources, faced with the multi-sectoral negative effects of the global recession (Figure 2).
- A new growth-based investment and export growth in the period 2015-2017 was characterized by the average annual growth of $1.8 \%$. Only in 2016, economic growth reached the pre-crisis level of 2008. At the end of 2017, the level of the GDP was at the level of 1977, which speaks about the extent of the economic distortions in the last decade of the $X X$ century.

By consistently implementing fiscal consolidation in the period 2015-2017, internal and external macroeconomic imbalances were reduced, a structural adjustment began, the economic and investment environment improved, as confirmed by renowned international institutions (WB, IMF, EBRD, WEF).

A comparative analysis of the economic growth trends in the SEE transition countries shows the different effects of the economic recession from one country to another, with some economies having managed to overcome the prior negative crisis strikes on their economies, primarily thanks to the resilience of their processing sectors (Table 1).

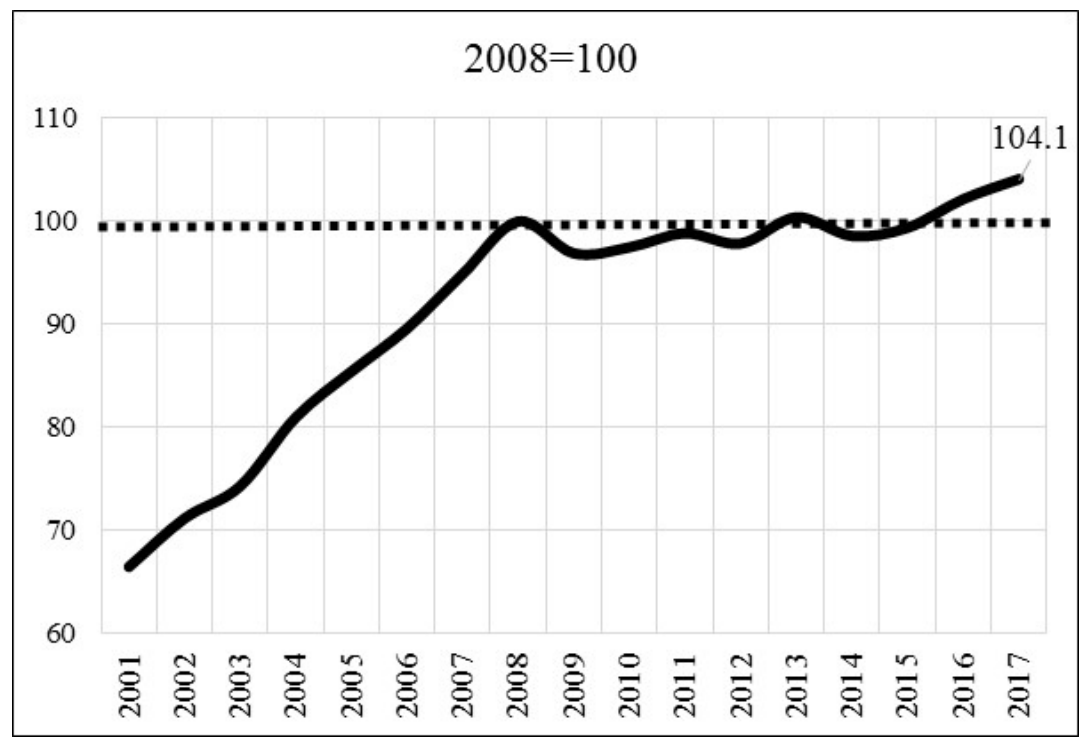

Figure 2 The impact of the crisis on economic growth in the Republic of Serbia 
Table 1 Economic growth in the transition countries of the region

\begin{tabular}{|c|c|c|c|c|}
\hline \multirow[t]{2}{*}{ State } & \multicolumn{2}{|c|}{$\begin{array}{l}\text { Rates of } \\
\text { growth/decline } \\
\text { in GDP }\end{array}$} & \multicolumn{2}{|c|}{$\begin{array}{l}\text { GDP per capita } \\
2016\end{array}$} \\
\hline & $\begin{array}{l}2001- \\
2008\end{array}$ & $\begin{array}{l}2009- \\
2016\end{array}$ & EUR & $\begin{array}{l}\text { PPS EU- } \\
28=100\end{array}$ \\
\hline Albania & 6.0 & 2.4 & 3,700 & 30 \\
\hline $\begin{array}{l}\text { Bosnia and } \\
\text { Herzegovina }\end{array}$ & 4.9 & 0.9 & 4,400 & 31 \\
\hline Bulgaria & 5.8 & 1.1 & 6,748 & 48 \\
\hline FYR Macedonia & 3.0 & 2.2 & 4,691 & 38 \\
\hline Romania & 6.3 & 1.1 & 8,640 & 59 \\
\hline $\begin{array}{l}\text { Republic of } \\
\text { Serbia }\end{array}$ & 5.9 & 0.3 & 4,904 & 36 \\
\hline Croatia & 4.3 & -1.1 & 11,142 & 59 \\
\hline Montenegro & 5.0 & 1.1 & 6,354 & 42 \\
\hline Slovenia & 4.2 & -0.3 & 19,574 & 83 \\
\hline Hungary & 3.2 & 0.6 & 11,588 & 67 \\
\hline
\end{tabular}

Source: Eurostat, RZS

The pre-crisis period 2001-2008 was characterized by the dynamics of Serbia's economic activities being above the average of the countries in the region. In the period 2009-2016, Albania and Macedonia recorded the highest GDP growth, whereas the highest decline was recorded in Croatia (Table 1). In the majority of the countries of the region, domestic demand (investments and private consumption) had a dominant influence on economic growth. Only in Bulgaria, the net exports made a greater contribution than domestic demand.

Above all, the effects of transition reflected in the standard of living in these countries. The living standard in RS in 2016 (the GDP per capita being
4,904 EUR) was higher than in Albania, Macedonia and Bosnia and Herzegovina, but simultaneously lower than the living standard in Bulgaria (by 37\%), Romania (by 76\%), Croatia and Hungary (2.3 times) and Slovenia (4 times). Compared to the purchasing power, $\mathrm{RS}$ is at $36 \%$ of the EU-28 average (the GDP per purchasing power), which is well below the developed transition countries in the region (Hungary lags behind the EU average of $33 \%$, Croatia $41 \%$ and Slovenia 17\%).

In the pre-crisis period, the employment rate did not change, the unemployment rate fell to $14.9 \%$, inflation was reduced, but was still high, FDIs experienced significant growth, the current account deficit was high, and the public debt was kept under control. The impact of the recession mostly affected the increase in the external debt and the decline in investment (both gross investments and FDIs). The positive macroeconomic results in the post-crisis period are fiscal consolidation (the reduction in the fiscal deficit) and the lowering inflation, below $3 \%$.

The analysis of the transformation period 20012017 shows the degree of the unsustainability of the growth model in the period 2001-2008, the negative effects in the recession period 2009-2014, primarily a rise in unemployment, a fall in the living standards and the debt growth and a change in the growth patterns over the last few years (Jakopin, 2018, 43). The consequences of the transformation model of "debt economies" reflected in all of the developmental dimensions ranging from demographic regression, via industrial devastation, the educational gap, regional imbalances, to institutional non-construction.

A shift and change in the new model of economic growth are most plausible according to the analysis of the expenditures structure of the contribution to the GDP growth (Figure 3). The pre-crisis growth model for the period 2001-2008 had almost exclusively been based on the growth of personal consumption, which was understandable to a certain degree, bearing in mind the consequences of the economic distortion on the living standard of the population in the last decade of the last century. The contribution of personal consumption to growth was constantly around 5\%, 


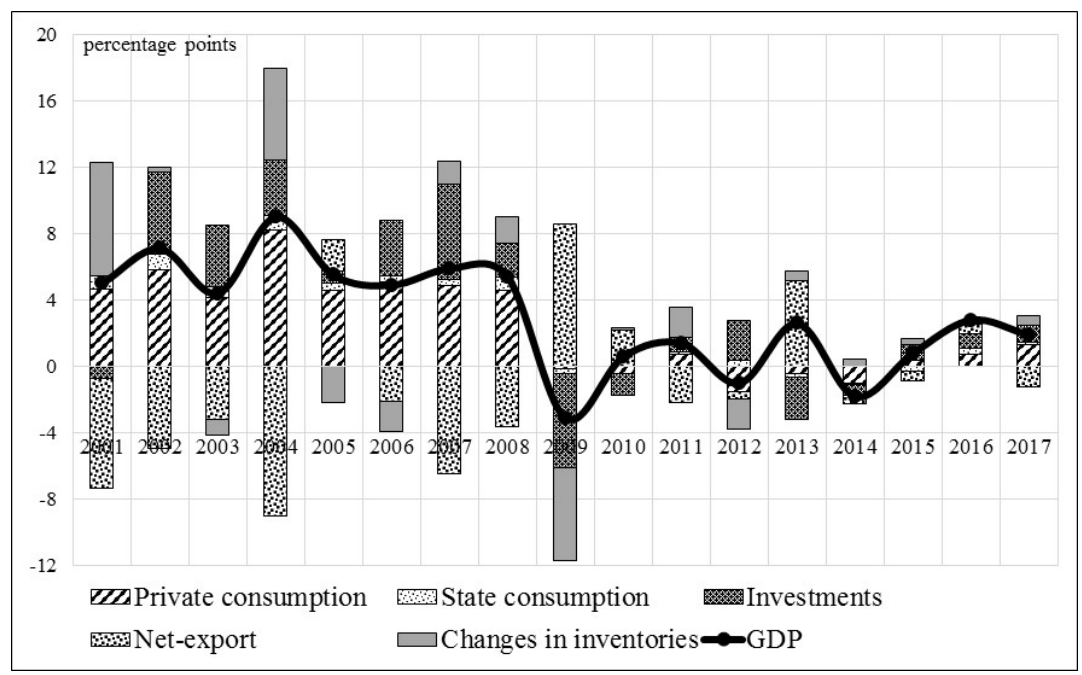

Figure 3 The models growth-structures contribution to the GDP growth in the Republic of Serbia

Source: Author

while, for example in 2008 , it was as much as $8 \%$. The foreign trade deficit was of a permanent character and the contribution of investments to economic growth was mainly made through the privatization process. State consumption also contributed to the growth achieved by 2009 .

During the recession period, there was a drastic fall in personal consumption and investment, whereas a significant drop in the contribution to the recession was also visible in the foreign trade deficit. In 2015, a positive contribution of investments was registered for the first time, which continued in 2016 and 2017. After five recession years, $\mathrm{f}$ the focus from the growth model based on the growth of consumption slowly shifted in 2015 to the growth model based on investment and, after a long time, on personal consumption. The contribution of personal consumption had an upward trend which resulted in a contribution of 0.4 percentage points in 2015, 0.7 percentage points in 2016, and 1.3 percentage points in 2017.

\section{INSTITUTIONAL TRANSITION}

The theorists of institutional transition define the very notion of institutions broadly, most often as the "formal and informal rules and their implementation mechanisms that shape the behavior of individuals and organizations in society" (Burki and Perry, 1998). Formal institutions are laws, regulations and contracts, whereas informal ones are: trust, ethics and political norms. Political institutions (legislative, political parties, government agencies), economic institutions (private companies, trade unions, business associations) and social institutions (NGOs, schools) are distinguished. The institutional growth theorists who claim that institutions dominate politics define institutions as

"a group of social arrangements that contain constitutional and social constraints based on the power of politicians and elites, the rule of law, provisions for mediation in social conflicts, the strong enforcement of property rights, a minimum volume of equal opportunities, and relatively broad access to education, etc." (Acemoglu, Johnson, \& Robinson, 2005). 
Similarly, one group of authors define institutions as "the rules of the game in the society and their contribution to desirable economic behavior" (Rodrik, Subramanian \& Trebbi, 2004), especially emphasizing the rule of law and the protection of property rights. "Institutions are primary to the rule of law" and "law enforcement" (Dollar \& Kraay, 2002).

The theoretical framework of the connection between institutional development and economic growth is extremely diverse. E. L. Jones (1981), D. North (1990), S. Knack and Ph. Keefer (1995), P. Mauro (1995), W. Easterly and R. Levine (2003), D. Acemoglu, S. Johnson and J. A. Robinson (2005), S. L. Engerman and S. Sokoloff (2010), and others have made a significant contribution to the construction of institutions and economic development. The crucial factor of successful transitional results is the efficiency of newly-established institutions (Hoff \& Stiglitz, 2004).

Perhaps one of the biggest shortcomings in the imposed reform agenda intending to help transitional economies is inconsistency and selectivity in strengthening the institute of the rule of law, property rights and the investment climate (all being more or less closely related). The definition of the World Bank insists on the efficiency of institutions, does not put an emphasis on the development of an institute, for example, the rule of law, a long and systemically demanding process implicative of social implications.

The reform agenda of the institutional transition focuses on the rule of law, law enforcement, access to knowledge and education, political participation, social equity and solidarity, tolerance and accountability.

According to the theoretical concept stipulating that institutional transition involves three key factors, namely the process of electing and controlling power, the institutional adoption and implementation of policies, and the development of institutions for the purpose of serving citizens, Daniel Kaufmann, Aart Kraay and Massimo Mastruzzi created the composite Indicators of Effective Institutional Management (Worldwide Governance Indicators, WGI) and developed a methodology for monitoring institutional transition in transition countries (Kaufmann, Kraay
Mastruzzi, 2010). The methodology consists of 6 composite sub-indices (dimensions):

- Voice and Accountability (VA) - This index provides pieces of information on the extent to which citizens can participate in choosing their government, the freedom of expression, the freedom of association and the free media.

- Political Stability and Absence of Violence/ Terrorism (PV) - This index provides pieces of information on the likelihood that the government will be destabilized or destroyed by unconstitutional or violent means, including politically motivated violence and terrorism.

- Government Effectiveness (GE) - This index includes pieces of information on the quality of public services, the quality of the civil service and the degree of its independence from political pressures.

- Regulatory Quality (RQ) - This index provides pieces of information on the government's ability to formulate and apply the sound policies and regulations that allow and promote the development of the private sector.

- Rule of Law (RL) - This index provides pieces of information on the extent to which institutions trust and respect a company's rules, in particular regarding the quality of contract performance, respect for property rights, the work of the police and courts, as well as the assessments of a possible crime and violence.

- Control of Corruption (CC) - This index includes pieces of information on how much public authority is used to achieve a private gain, including small and large forms of corruption, as well as the degree of the abuse of state institutions by elites and private interests.

The methodology includes several hundred variables from 31 different sources of data, including management perceptions, such as respondents' reports, non-governmental organizations, commercial information providers and public sector organizations around the world. The databases for 200 countries in the world have been existent since 1996. The 
composite indicator WGI, expressed through the equation system, is expressed in standard normal units (ranging from -2.5 to 2.5 ).

Transition economies have advanced in building institutions, but with varying dynamics, and at different times. In 2000, Serbia had the largest institutional gap in relation to other transition countries (WGI -1.07). In the period 2001-2008, the SEE countries significantly strengthened their new institutions, so that in the period of the recession, the institutional strengthening process of most transition economies was stopped (Table 2). In Bulgaria, Hungary and Slovenia, the recession and the decline in economic growth resulted in the breakdown of institutions. Institutions are the weakest in the least developed countries: Albania, Bosnia and Herzegovina and Moldova (the WGI has a negative value).

Table 2 Measuring Institutional Progress

\begin{tabular}{|c|c|c|c|c|}
\hline \multirow{2}{*}{ State } & \multicolumn{4}{|c|}{ WGI-average } \\
\hline & 2000 & 2008 & 2009 & 2016 \\
\hline Albania & -0.62 & -0.21 & -0.16 & -0.02 \\
\hline $\begin{array}{l}\text { Bosnia and } \\
\text { Herzegovina }\end{array}$ & -0.52 & -0.34 & -0.37 & -0.32 \\
\hline Bulgaria & 0.13 & 0.20 & 0.25 & 0.18 \\
\hline Croatia & 0.17 & 0.37 & 0.39 & 0.45 \\
\hline FYR Macedonia & -0.50 & -0.07 & -0.05 & -0.12 \\
\hline Moldova & -0.42 & -0.43 & -0.45 & -0.41 \\
\hline Montenegro & -0.61 & 0.09 & 0.15 & 0.07 \\
\hline Romania & -0.18 & 0.13 & 0.14 & 0.25 \\
\hline $\begin{array}{l}\text { Republic of } \\
\text { Serbia }\end{array}$ & -1.07 & -0.26 & -0.17 & 0.01 \\
\hline SEE-average & -0.40 & -0.06 & -0.03 & 0.01 \\
\hline Slovenia & 0.89 & 1.03 & 1.03 & 0.94 \\
\hline Hungary & 0.97 & 0.84 & 0.74 & 0.48 \\
\hline Czech Republic & 0.56 & 0.92 & 0.92 & 0.96 \\
\hline
\end{tabular}

Source: Author, based on Worldwide Governance Indicators
An analysis of the institutional sub-indexes of the WGI shows that (Table 3):

- the biggest institutional weakness and the weakest institutional transition results in the SEE area in 2016 were the rule of law (the average of the RL sub-indices of the SEE countries being -0.11) and the control of corruption (the average of the subindex CC being -0.28);

- the biggest breakthrough was made by the institutions in the field of political stability (the PV sub-index moved from the vast negative zone of -0.66 at the beginning of the transition in 2000 to the positive zone) and regulatory quality (the sub-line RQ from -0.32 in 2000 entered the positive zone at +0.25 );

- the effects of the global recession had the most negative impact on the Freedom of Speech and Accountability (VA) sub-indices - not only had there been no progress in the period 2008-2016, but the average of the VA sub-index worsened (in Hungary, the decline was -0.60 index points, in Macedonia -0.43, in Bulgaria -0.14, in Montenegro -0.16 , and in Serbia -0.07). Interestingly, the postcrisis decline was registered in the successful transition countries of Hungary and Slovenia. In the same period, the Political Stability Institute recorded a slight improvement (from 0.02 to 0.04), but a decline was registered in three more developed countries;

- Bosnia and Herzegovina and Moldova are institutionally extremely inefficient, their subindices are in the negative zone, so that the two countries (together with Albania in the RL and CC sub-indices) largely "spoil" the average of the entire SEE region;

- the Government Efficiency Institute was improved in the 2014-2016 period in Albania, Bulgaria and Serbia;

- a decline in the Regulatory Quality (RQ) subindex in the post-crisis period was particularly reflected in the transition countries of the EU: in the Czech Republic (from 1.15 to 1.08), in Hungary 
Table 3 Institutional Transition in Transition Countries WGI 2000-2016

\begin{tabular}{l|cc|cc|cc|cc|cc|cc}
\hline \multirow{2}{*}{ Country } & \multicolumn{2}{|c|}{ VA } & \multicolumn{2}{c|}{ PV } & \multicolumn{2}{c|}{ GE } & \multicolumn{2}{c|}{ RQ } & \multicolumn{2}{c}{ RL } & \multicolumn{2}{c}{ CC } \\
& 2000 & 2016 & 2000 & 2016 & 2000 & 2016 & 2000 & 2016 & 2000 & 2016 & 2000 & 2016 \\
\hline Albania & -0.29 & 0.16 & -0.54 & 0.26 & -0.76 & 0.00 & -0.25 & 0.20 & -1.01 & -0.35 & -0.86 & -0.40 \\
Bosnia and Herzegovina & -0.11 & -0.16 & -0.53 & -0.38 & -0.84 & -0.43 & -0.50 & -0.18 & -0.61 & -0.29 & -0.56 & -0.47 \\
Bulgaria & 0.46 & 0.44 & 0.38 & 0.03 & 0.00 & 0.29 & 0.20 & 0.55 & -0.12 & -0.04 & -0.13 & -0.16 \\
Croatia & 0.51 & 0.52 & 0.28 & 0.68 & 0.33 & 0.49 & -0.03 & 0.36 & 0.03 & 0.44 & -0.07 & 0.19 \\
FYR Macedonia & -0.34 & -0.23 & -0.62 & -0.38 & -0.75 & 0.09 & -0.13 & 0.45 & -0.57 & -0.31 & -0.60 & -0.31 \\
Moldova & -0.14 & -0.03 & -0.43 & -0.28 & -0.51 & -0.62 & -0.29 & -0.05 & -0.48 & -0.54 & -0.66 & -0.96 \\
Montenegro & -0.50 & 0.08 & -1.64 & 0.16 & -0.85 & 0.10 & -0.86 & 0.23 & 0.34 & -0.04 & -0.17 & -0.10 \\
Romania & 0.47 & 0.51 & -0.38 & 0.27 & -0.37 & -0.17 & -0.11 & 0.59 & -0.20 & 0.30 & -0.49 & 0.00 \\
Republic of Serbia & -0.64 & 0.21 & -1.64 & 0.05 & -0.85 & 0.09 & -0.86 & 0.14 & -1.27 & -0.12 & -1.18 & -0.31 \\
SEE-average & -0.06 & 0.17 & -0.57 & 0.04 & -0.51 & -0.02 & -0.31 & 0.25 & -0.43 & -0.11 & -0.52 & -0.28 \\
Slovenia & 1.11 & 1.00 & 0.89 & 0.99 & 0.75 & 1.12 & 0.69 & 0.62 & 1.04 & 1.08 & 0.88 & 0.80 \\
Hungary & 1.14 & 0.37 & 0.92 & 0.71 & 0.98 & 0.45 & 1.09 & 0.77 & 0.91 & 0.51 & 0.79 & 0.08 \\
Czech Republic & 0.76 & 1.05 & 0.33 & 0.99 & 0.65 & 1.06 & 0.76 & 1.08 & 0.64 & 1.09 & 0.21 & 0.51 \\
\hline
\end{tabular}

Source: Worldwide Governance Indicators

(from 1.19 to 0.77 ), in Croatia (from 0.51 to 0.36 ), in Bulgaria (from 0.69 to 0.55 ) and in Slovenia (from 0.83 to 0.62 ), which forced the governments of these countries to pay much more attention to the institutional regulation of the private sector.

Institutional Transition in RS in the transition period 2000-2016 was carried out with different dynamics and intensity (Figure 4):

- at the beginning of the institutional transition, all of the institutional sub-indices had the maximum negative values: Political Stability was at a record minimum (PV -1.64), Control of Corruption (CC -1.18), Regulatory Quality (RQ -0.86), Government Efficiency (GE -0.85), Freedom of Speech (VA -0.64) and Rule of Law (RL -1.27);

- in the pre-crisis period until 2008, the greatest institutional breakthroughs were achieved in the Freedom of Speech (VA 0.28), Government Efficiency (GE -0.19) and Corruption Control (CC -0.31) sub-indices;

- in the crisis period 2009-2013, all of the WGI sub- indices showed slight fluctuations, or worsened, or stagnated;

- in the period 2014-2016, Political Stability (PV), Government Efficiency (GE) and Regulatory Quality (RQ) were improved and located in the positive sub-indices zone;

- the most critical institutional indicator for RS is the constant Control of Corruption (CC) and the Rule of Law (RL), but according to Regulatory Quality (RQ), it is below the SEE average;

- Serbia lags most behind the most successful transition countries with respect to the indicators of the Rule of Law (RL), Government Efficiency (GE), and Regulatory Quality (RQ).

\section{CORRUPTION AS A FACTOR OF INSTITUTIONAL DEGRADATION}

Institutional non-construction is one of the key factors for corruption growth in underdeveloped economies, 


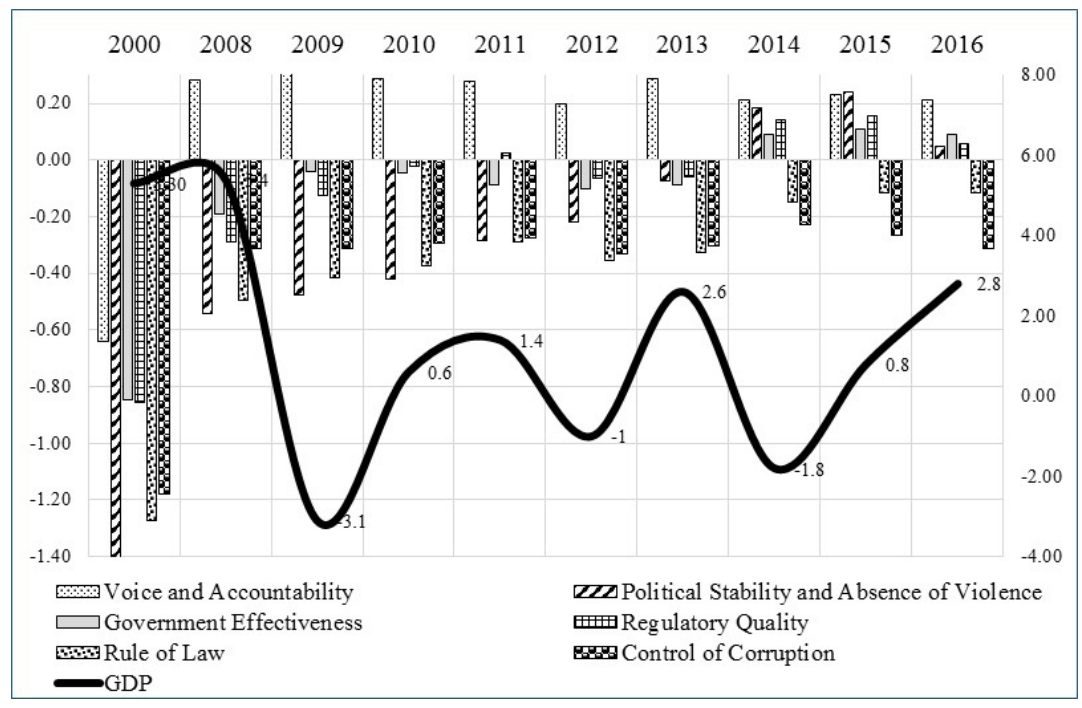

Figure 4 The effects of the crisis on institutional transition and economic growth in the Republic of Serbia

Source: Author

in which market institutions are still developing. It is difficult to unwrap the "vicious circle" of bureaucratic inefficiency and the growth of corruption - what is the cause, and what the consequences. The matrix of the corruption factor (positive and negative) is shown in Table 4.

The influence of unenclosed institutions on the business investment climate was empirically proved, and a fact was established that the high levels of corruption reduce a country's economic growth, investment climate and investment quality. The effects of corruption destroy institutions and economic growth, cause an inefficient asset allocation, and reduce productivity. Particularly negative is the effect of the degree of corruption on attracting FDIs. As a rule, the investment process involves obtaining a variety of public licenses, which may require a form of bribery, which increases investment costs and reduces the total inflow of FDIs (Saha, Rukmani \& Jen-Je, 2009).

Corruption increases the inequality of income (the growth of the Gini coefficient) and poverty through a reduction in growth, the tax system, social programs of a poor quality, inequality in education and the bias of property ownership (Tanzi, 1998). The effects of the growth of the gray economy which transition economies are faced with affect such economies. In order to combat the gray economy, almost all transition countries adopted strategic documents and action plans. In the period 2012-2017, the Serbian government reduced the size of the gray economy from $21.2 \%$ to $15.4 \%$, but in many institutional segments, there is considerable room for increasing the efficiency of fighting against the gray economy.

The emergence of institutionalized non-construction and corruption particularly affects transition countries through "brain drain" and the quality of human capital. A fact was empirically established that the high levels of corruption affect the level of the emigration of qualified labor far beyond unskilled labor (Dimant, Krieger \& Meierrieks, 2013). Higher levels of corruption are associated with lower levels of education, health, socio-economic development, which affects reduction in human capital levels. 
Table 4 The Corruption Factor Matrix

\begin{tabular}{l|l}
\hline+ (an increase in corruption) & -(a reduction in corruption) \\
\hline Bureaucracy and ineffective administrative and & Citizens' participation/the freedom of the \\
political structure & press \\
(Tanzi, 1998, Goel and Nelson, 2010) & (Bhattacharyya and Hodler, 2010) \\
Weak institutions & Economic growth, investments \\
(Pellegrini and Gerlagh, 2007) & (Pellegrini and Gerlagh, 2007) \\
"Resource curse" & Higher levels of the economic freedom, the \\
(Bhattacharyya and Hodler, 2010) & freedom of choice, less economic control (Saha, \\
& Gounder and Su, 2009) \\
Political instability & Globalization \\
(Goel and Nelson, 2010) & (Charron, 2009) \\
Poverty & $\begin{array}{l}\text { Decentralization } \\
\text { (Tanzi, 1998, Goel and Nelson, 2010) }\end{array}$ \\
The low level of property rights protection & The market and competition \\
(Pellegrini and Gerlagh, 2007) & (Alexeev and Song, 2013) \\
Low earnings & Trade openness \\
(Goel and Nelson, 2010) & (Charron, 2009) \\
The effects of the environment & Transparency \\
(Goel and Nelson, 2010) & (Goel and Nelson, 2010) \\
Lower education & eGovernment \\
(Pellegrini and Gerlagh, 2007) & (Elbahnasawy, 2014) \\
Immigration from a highly corrupt country & The Internet \\
(Dimant, Krieger and Meierrieks, 2013) & (Goel and Nelson, 2010) \\
\hline
\end{tabular}

Source: Author, based on the cited papers

\section{CONCLUSION}

We are undergoing turbulent global economic changes. The basic characteristics of these changes are:

- first, neoliberal globalism contributes to an increasing social polarization;

- second, there is a progressively increasing marginalization of and alienation from the production process, which leads to the disappearance of the social framework within which a profit could be socially divided;
- third, there are permanent changes in the business cycle and the climate of a permanent downward recession is created; ultimately, the deregulation of global trade exacerbates structural imbalances and does not lead to structural adjustments.

The influence of these processes directly causes "the state elites to engage themselves in a race towards lower competitor strategies" (Jakopin, 2017b, 115).

In the transformation period lasting for almost three decades now, transition countries can see significant differences in institutional and economic development. In the SEE region, the differences between the EU member states and those candidate 
ones are increasingly more noticeable in terms of economic (the rate and sustainability of economic growth) and in institutional terms (efficient and stable institutions in the function of economic growth). The global recession had a devastating effect on the degradation of the already fragile institutions of the SEE region (Jakopin, 2018, 51-54). In addition to the late transition phase (Serbia, Bosnia and Herzegovina, Macedonia), institutional and economic policies were influenced by the institutional reforms.

The influence the institutions have on economic growth and development is directly felt through the efficiency of the state (the regulatory, allocative, and incentive functions), especially in the crisis periods when the imperfection of the market, as a convergence instrument, is manifest. An effective institutional framework creates the business environment, instruments, mechanisms and measures for sustainable economic growth. Countries characterized by a high degree of the rule of law have a rate of economic growth three times as high. In addition to the delayed transition and the political legacy, the SEE's economic periphery should also be sought for the reason of the fact that, first of all, the institutional transition has not been successfully implemented.

According to the results of the research work done, the following conclusions can be drawn:

- The applied transitional models of economic growth were not in the function of building stable institutions. Institutional construction was shadowed by the ownership structure transformation process. The inadequacy and inefficiency of institutions directly influenced the effects of the privatization process, as well as the post-privatization effects, not only in Serbia, but also in the surrounding countries.

- Throughout the transition period there is a permanent gap between reform laws and their implementation. Institutions without the law enforcement capacity not only create inconsistencies between the proclaimed and the real, but also encourage the marginalization and non-enforcement of law.
- The institutional gap is mostly contributed to by the corruption factor, which is "fed" by bureaucracy, inefficient administration, low wages and poverty.

- Institutions are faced with the major problem of openness, which is evident from the central to the local level of institutional closure, and non-transparency is growing. The Center for Democratic Transition conducted a research study of the openness of institutions (governments, assemblies, ministries and administration bodies) in the countries of Montenegro, Republic of Serbia, Bosnia and Herzegovina, and FYR Macedonia (October-December 2016) and the obtained results based on the Regional Open Source Index show high institutional closeness, selectivity and arbitrariness (for example, the Serbian authorities were opened $56 \%$, whereas that percentage was $66 \%$ in Montenegro, 36\% in Macedonia and $44 \%$ in $\mathrm{B} \& \mathrm{H})$. The concept of open governments during the EU integration process did not fully survive, and society's essential need for the necessity of applying and promoting reform values and their positive impact on the citizens was not recognized. In this context, it is necessary to continuously conduct research studies of the openness of institutions at all the levels of government.

The contribution of the research study reflects in the testing of the initial hypothesis of the interaction between institutional transition and economic growth indicates that the influence of institutions on transition economic growth in Serbia was negligible, and the reverse influence, i.e. the impact of economic growth on the development of institutions is the only such interest we can speak about. In the period 20012008, when the average rate of economic growth in Serbia was $5.9 \%$, all of the indicators of institutional efficiency recorded significant growth. By contrast, in the recession period until 2014, deprived of virtually any growth at all, the largest number of the indicators of institutional efficiency experienced either a decline or stagnation. A mild recovery and growth in the period 2015-2017 reflected the improvement of a number of institutional indicators (political stability, government efficiency and regulatory quality). 
The final message to the economic policy makers is: as sustainable economic growth is impossible without stable and efficient institutions, no stable or efficient institutions are possible, either, in recessionary periods, or in the periods of low economic growth rates.

\section{REFERENCES}

Acemoglu, D., Johnson, S., \& Robinson, J. A. (2005). Institutions as the fundamental cause of long-run growth. In P. Aghion, \& S. Durlauf (Eds.). Handbook of Economic Growth Volume $1 A$ (pp. 385-472). Amsterdam, North Holland: Elsevier B.V. doi:1O.1016/S1574-W84(05)OloW

Alexeev, M., \& Song, Y. (2013). Corruption and product market competition: An empirical investigation. Journal of Development Economics, 103(1), 154-166. doi.org/10.1016/j. jdeveco.2013.02.010

Bhattacharyya, S., \& Hodler, R. (2010). Natural resources, democracy and corruption. European Economic Review, 54(4), 608-621. doi.org/10.1016/j.euroecorev.2009.10.004

Burki, S. J., \& Perry, G. (1998). Beyond the Washington Consensus: Institutions Matter. Washington, DC: World Bank.

Charron, N. (2009). The impact of socio-political integration and press freedom on corruption. The Journal of Development Studies, 45(9), 1472-1493. doi.org/10.1080/00220380902890243

Dell'Anno, R., \& Teobaldelli, D. (2015). Keeping both corruption and the shadow economy in check: The role of decentralization. International Tax and Public Finance, 22(1), 1-40. doi:10.1007/s10797-013-9298-4

Dimant, E., Krieger, T., \& Meierrieks, D. (2013). The effect of corruption on migration 1985-2000. Applied Economics Letters, 20(13), 1270-1274. doi.org/10.1080/13504851.2013.806 776

Dollar, D., \& Kraay, A. (2002). Institutions, trade, and growth. Journal of Monetary Economics, 50(1), 133-162. doi.org/10.1016/ S0304-3932(02)00206-4

Easterly, W., \& Levine, R. (2003). Tropic, germs and crops: How endowments influence economic development. Journal of Monetary Economics, 50(1), 3-39. doi.org/10.1016/ S0304-3932(02)00200-3
Elbahnasawy, N. G. (2014). E-government, internet adoption, and corruption: An empirical investigation. World Development, 57(C), 114-126. doi: 10.1016/j. worlddev.2013.12.005

Engerman, S. L., \& Sokoloff, S. (2000). History lessons: Institutions, factor endowments, and paths of development in the new world. Journal of Economic Perspectives, 14(3), 217232. doi:10.1257/jep.14.3.217

Goel,K.R.,\&Nelson, A.M.(2010). Causes of corruption:History, geography and government. Journal of Policy Modeling, 32(4), 433-447. doi.org/10.1016/j.jpolmod.2010.05.004

Hoff, K., \& Stiglitz, E. J. (2004). After the big bang? Obstacles to the emergence of the rule of law in post-communist societies. American Economic Review 94(3), 753-763. doi:10.1257/0002828041464533

Jakopin, E. (2017a). Smart specialisation of manufacturing industry: Relying on one's own strengths and targeted attraction of FDI. Ekonomika preduzeća, 65(1-2), 155-173.

Jakopin, E. (2017b). Privredni rast i institucionalne performanse u tranzicionim državama JIE. Ekonomija danas, Institucije - šta (ne)možemo uraditi bolje, 105-118.

Jakopin, E. 2018. Regionalna tranzicija Srbije. Beograd, Republika Srbija: Zadužbina Andrejević.

Jones, E. L. 1981. The European Miracle: Environments, Economies, and Geopolitics in the History of Europe and Asia. New York, NY: Cambridge University Press.

Kaufmann, D., Kraay, A., \& Mastruzzi, M. (2010). The worldwide governance indicators: Methodology and analytical issues. Working Paper Series 5430, WB.

Knack, S., \& Keefer, Ph. (1995). Institutions and economic performance: Cross-country tests using alternative institutional measures. Economics and Politics, 7(3), 207-227. doi.org/10.1111/j.1468-0343.1995.tb00111.x

Mauro, P. (1995). Corruption and growth. Quarterly Journal of Economics 110(3), 681-712. doi.org/10.2307/2946696

North, D. 1990. Institutions, Institutional Change, and Economic Performance. New York, NY: Cambridge University Press.

Pellegrini, L., \& Gerlagh, R. (2007). Causes of corruption: A survey of cross-country analyses and extende results. Economics of Governance 9(3), 245-263. doi:10.1007/s10101-0070033-4 
Rodrik, D., Subramanian, A., \& Trebbi, F. (2004). Institutions rule: The primacy of institutions over geography and integration in economic development. Journal of Economic Growth, 9(2), 131-165. doi:10.3386/w9305

Saha, S., Rukmani, G., \& Jen-Je, S. (2009). The interaction effect of economic freedom and democracy on corruption: A panel cross-country analysis. Economics Letters, 105(2), 173176.
Tanzi, V. (1998). Corruption around the world: Causes, consequences, scope, and cures. IMF Working Paper No. 98/63, 1-39.

$$
\begin{array}{r}
\text { Received on } 4^{\text {th }} \text { April 2018, } \\
\text { after revision, } \\
\text { accepted for publication on } 22^{\text {nd }} \text { August } 2018 \\
\text { Published online on } 27^{\text {th }} \text { August } 2018
\end{array}
$$

Edvard A. Jakopin is the Head of the Department for Strategic Analysis and Industrial Policy of the Ministry of Economy of the Republic of Serbia. He obtained his Ph.D. at the Faculty of Economics of the University of Belgrade. He is the author of numerous scientific and expert papers in the field of macroeconomics, economic development planning, structural changes, competitiveness, regional modeling. 


\title{
PRIVREDNI RAST I INSTITUCIONALNA TRANZICIJA REPUBLIKE SRBIJE
}

\author{
Edvard Jakopin* \\ Ministarstvo privrede Republike Srbije
}

Da li se tranzicione države Jugoistočne Evrope (JIE) nalaze zarobljene $\mathrm{u}$ institucionalnoj tranziciji? Institucionalna tranzicija koja traje skoro tri, a u Republici Srbiji skoro dve decenije, započela je brzim uništavanjem institucija iz prethodnog političkog i ekonomskog sistema, ali, izgradnja novih tržišnih institucija se odvija sporo, neefikasno i parcijalno. Republika Srbija je izgubila tri decenije privrednog rasta i razvoja, što potvrđuje ekonomsku zakonitost da je potrebno dvostruko više vremena vratiti sistem u prethodni ekvilibrijum od dužine vremena u kome se sistem nalazio van ravnoteže. Prosečan rast za sedamnaest tranzicionih godina od 3\% je nedovoljan da se nadoknadi ogroman zaostatak iz devedesetih godina XX-og veka. Istraživački doprinos u radu fokusiran je na analizu međuzavisnosti privrednog rasta i izgradnje institucija. Posebna pažnja usmerena je na faktor korupcije, koja razara institucije u svim tranzicionim državama, smanjuje privredni rast, produktivnost i negativno utiče na privlačenje stranih direktnih investicija (SDI).

Ključne reči: privredni rast, institucionalna tranzicija, korupcija

\section{UVOD}

Jedinstveni eksperiment institucionalne tranzicije u tranzicionim državama Evrope traje skoro tri decenije, a u Republici Srbiji (RS) punih sedamnaest godina. Institucionalna tranzicija $\mathrm{u}$ državama Jugoistočne Evrope (JIE) započela je brzim napuštanjem institucija iz prethodnog političkog i ekonomskog sistema, ali, izgradnja novih tržišnih institucija je bila mnogo sporija i neefikasnija, sa različitom dinamikom

* Korespondencija: E. Jakopin, Ministarstvo privrede Republike Srbije, Vlajkovićeva 10, 11000 Beograd, Republika Srbija; e-mail: edvard.jakopin@privreda.gov.rs izgradnje od zemlje do zemlje, u zavisnosti od brzine sprovođenja strukturnih reformi i ulaska u Evropsku uniju (EU).

Konkretno, od svih tranzicionih država, u prvoj deceniji tranzicije, samo su Estonija, Mađarska i Poljska izgradile institucije koje bi osigurale zaštitu imovinskih prava i sprovele regulatornu reformu poslovnog okruženja za podsticanje investicija. Litvanija i Slovačka, i pored implementacije značajnih makroekonomskih reformi, dugo nisu uspele da se pridržavaju teških budžetskih ograničenja za subvencije državnim preduzećima. Jedan broj država (Moldavija, Rusija, Ukrajina), zaglavio se u 
Łzv. reformskoj zamci, bez suštinskih reformi (forma umesto reforme), jer se prethodni sistem reciklirao kroz proces privatizacije i liberalizacije (Jakopin, 2017b, 106). Generalno, jedan broj država u tranziciji uspeo je da izgradi novi institucionalni okvir nakon napuštanja socijalizma, ali je većina tranzicionih država i dalje zarobljena u institucionalnoj tranziciji.

Tranzicione privrede, koje su pretežno oslonjene na resursne, radno-intenzivne privredne grane, po pravilu, više su odgovarale elitama koje nisu zainteresovane za institucionalni okvir (stara nomenklatura koja je imala koristi od privatizacije ili novoizgrađena grupa vlasnika preduzeća). Razloge veoma spore izgradnje tržišnih institucija $u$ tranzicionim državama neki autori traže u prethodnoj velikoj privrednoj zavisnosti od prirodnih resursa i u istorijskom iskustvu ovih zemalja tokom socijalizma (Bhattacharyya \& Hodler, 2010).

Predmet istraživanja $u$ radu su institucionalne performanse tranzicije Republike Srbije, sa posebnim istraživačkim ciljem analize međuzavisnosti privrednog rasta i institucionalne tranzicije u RS i tranzicionim državama JIE, od kojih se većina nalazi u predvorju EU.

$\mathrm{U}$ radu se testira hipoteza da bez razvoja stabilnih institucija nisu održive visoke stope privrednog rasta, kao i obrnuto, da bez visokih stopa privrednog rasta nije moguće izgraditi stabilne institucije. U okviru ove hipoteze analizirani su efekti globalne recesije na institucionalnu tranziciju i privredni rast.

U istraživanju su korišćeni metodi analize i sinteze, kompilacije i komparacije. Analiza institucionalne tranzicije se bazirala na kompozitnim Indikatorima efikasnog institucionalnog upravljanja (Worldwide Governance Indicators - WGI).

Rad je strukturiran u dve međusobno povezane celine. Prva istražuje performanse tranzicionog privrednog rasta u RS, a u drugoj je istraživački rakurs usmeren ka institucionalnoj tranziciji, sa posebnim osvrtom na analizu korupcije, kao faktora koji utiče na razgradnju institucija.

\section{IZGUBLJENE TRI DECENIJE RASTA}

Početak transformacije, 2001, privreda RS je dočekala sa strukturom formiranom pre skoro tri decenije. Nakon sedamnaest godina, kratak tranzicioni saldo bi glasio: zaostatak iz 1990-tih se sporo stiže, tek je na tri četvrtine puta, ne smanjuje se zaostatak u odnosu na grupu najrazvijenijih država u Evropi (EU-15), ali se povećava $u$ odnosu na grupu tranzicionih država koje su primljene u EU 2004 (EU-10).

Usled ekonomske distorzije u poslednjoj deceniji XX-og veka, sankcija i NATO bombardovanja, RS je izgubila tri decenije privrednog rasta i razvoja, što potvrđuje ekonomsku zakonitost da je potrebno dvostruko više vremena vratiti sistem $u$ prethodni ekvilibrijum od dužine vremena u kome se sistem nalazio van ravnoteže. Danas se privredni rast RS nalazi na nivou iz 1976, i iznosi svega 78,1\% proseka onog BDP iz 1990. (Slika 1). Sa prosečnom godišnjom stopom rasta od $4 \%$, biće potrebno još sedam godina za dostizanje nivoa BDP-a iz 1990.

Industrija RS prošla je pravi tranzicioni cunami. Danas $\mathrm{u}$ industriji RS radi više od pola miliona radnika manje nego 1990. U odnosu na 1990, indeks fizičkog obima industrijske proizvodnje, na kraju 2017, je dvostruko manji (51\%), i nalazi se na istom nivou na kom se nalazio i 1972.

Makroekonomski rizici održivosti privrednog rasta na kompletnom području JIE su permanentno prisutni, nezaposlenost je najveća u Evropi. Ekonomske disproporcije između JIE i EU su konstantno na ekstremnim granicama. Po svim ekonomskim parametrima, region JIE pripada periferiji EU. Životni standard u JIE je 2016. skoro tri puta niži u odnosu na prosek EU, a stopa nezaposlenosti tri puta viša. Regionalna i socijalna kohezija u Evropi je sve slabija, područje JIE suočeno je, sve više, sa različitim oblicima siromaštva i zaostalosti (Jakopin, 2017a, 157).

Tranzicione privrede JIE se sporo prilagođavaju procesu globalizacije, sve snažnijoj tržišnoj utakmici, visokim zahtevima konkurencije. Uspešne tranzicione ekonomije su, u drugoj polovini devedesetih godina, imale dinamičan privredni rast, pre svega, usled rasta investicija, lične potrošnje i većeg izvoza robe 


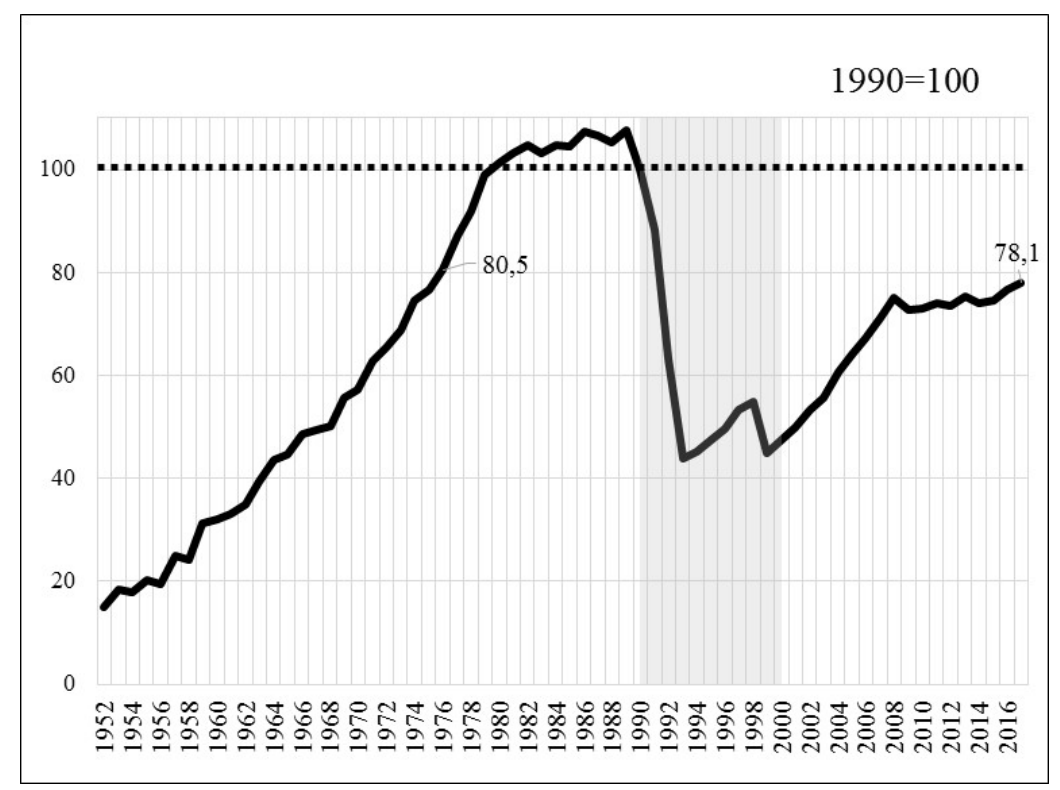

Slika 1 Izgubljene tri decenije rasta - BDP Republike Srbije 1952-2017

Izvor: Autor

Metodološka napomena: Zbog promena metodologije, za period 1952-2000 korišćena je serija kretanja društvenog proizvoda (u cenama 1994.), a u periodu 2001-2017. serija stopa rasta BDP (Jakopin, 2018, 36).

i usluga. Pokretač njihovog privrednog rasta bile su sprovedene strukturne reforme na osnovu kojih je došlo do značajnih promena u strukturi industrijske proizvodnje. Strukturne promene, vođene postulatom veće međunarodne konkurentnosti, uzrokovale su izuzetno dinamičan rast industrijskih grana zasnovanih na korišćenju savremene tehnologije i ekonomije obima, razvoju novih industrija, kreativne ekonomije.

Strukturne promene, sprovedene kroz priliv stranih direktnih investitica (SDI), rast industrijske proizvodnje i izvoz, doprinele su da većina tranzicionih zemalja Centralne i neke države JIE (članice EU) značajno povećaju svoje izvozne performanse, što je podiglo kompletne industrije ovih zemalja na viši nivo. Ključnu ulogu u procesu povećanja izvoza je odigralo tržište EU. Inovativni procesi u nauci, tehnologiji, u svim industrijskim granama odvijaju se sve većom brzinom u svetu i zaobilaze region JIE.

\section{TRANZICIONI MODELI RASTA}

Globalna recesija, nastala špekulativnim rastom cena i pucanjem mehura (balona) 2007, otvorila je brojne teorijske i praktične dileme, počev od izvora krize, uloge države, tržišnim deformacijama, sistemskim pojavnim oblicima krize, mobilnosti resursa, alternativnim rešenjima i modelima rasta (Jakopin, 2018, 38-44).

Neravnoteže su produbljene primenjenim modelom svojinske transformacije. Model je funkcionisao po principu kupovine vremena prihodima od privatizacije i prilivom SDI, tako što se nerestruktirirana izvozno neorijentisana privreda zaduživala i povećavala spoljni dug. S druge strane, unutrašnja stabilnost je uslovljena ogromnim viškom uvoza nad izvozom i precenjenim dinarom koji je taj veliki spoljnotrgovinski deficit podsticao i održavao. Precenjeni dinar bio je noseći stub antiinflacione politike, utičući na robne tokove, ali usled jeftinih uvoznih sirovina i repromaterijala, uticao je i na 
proizvodne troškove. U takvoj situaciji, globalna recesija je samo dolila ulje na vatru.

Kratak teorijski pregled uzroka globalne recesije. Uzročnici žarišta najveće krize od Velike depresije 1929-1933. leže u kombinaciji tri faktora:

- ogroman rast gramzivosti (pohlepe) privrednih subjekata (čuveni Kejnsov animal spirits),

- promašaji ekonomske politike, i

- zatečeni institucionalni okvir (regulativni sistem).

U recesionim periodima država je superioriornija od tržišta, pre svega, zato što ima instrumente da mobiliše resurse. Recimo, u svim varijantama, država da bi smanjila percepciju rizika, ekonomskom politikom podstiče brži razvoj preduzetništva. Generator izbijanja krize uvek je sistem, a ne država sa svojom politikom, jer je tržišni ekonomski sistem inherentno nestabilan. Država preko svojih instrumenata kreira strukturne reforme i menja sistem da bi minimizirala gubitke. Neki autori smatraju da ni rekonstrukcija sistema, niti preoblikovanje ekonomske politike ne mogu otkloniti uzroke krize. Jednom rečju, ključna odrednica recesije je sistemska nestabilnost. Pored sistemskih uzroka, recesione tegove su pojačavali nejak izvozni sektor i pogrešna ekonomska politika, koja se manifestovala, pre svega, kroz jaku domaću valutu. Povremeno hvatanje daha davali su prihodi od privatizacije, SDI i zaduživanje $u$ inostranstvu (Jakopin, 2018, 42).

Osnovne karakteristike predkriznog tranzicionog modela privrednog rasta u RS, u periodu 2001-2008, koje su imale najveći uticaj na privredni rast, mogu se opisati na sledeći način:

- proces privatizacije društvene svojine u privatnu nisu pratila konzistentna institucionalna rešenja, efekti su daleko manji od očekivanih;

- rast industrijske nezaposlenosti nije bio praćen rastom preduzetničkog sektora;

- privredni rast se zasnivao na rastu usluga, a ne na rastu privrednih grana - razmenjivih dobara (industrija, građevinarstvo);
- potrošnja je rasla brže od privrednog rasta, što je imalo za posledicu rast spoljnjeg duga;

- strukturne reforme u privredi su se odvijale sporo, selektivno i parcijalno.

Prosečna stopa privrednog rasta $\mathrm{u}$ tranzicionom periodu 2001-2017. je skromna, svega 3,0\%. Nakon dinamičkog privrednog rasta $u$ predkriznom periodu 2001-2008. (prosečna stopa privrednog rasta iznosila je 5,9\%), usledio je pad u kriznoj 2009. $(-3,1 \%)$ i višegodišnji recesioni period (prosečan pad stope privrednog rasta u periodu 2010-2014. iznosio je $-0,1 \%$ ), da bi u periodu 2015-2017. usledili blagi znaci oporavka privrednog rasta (prosečan rast je iznosio $1,8 \%$ ).

Transformacioni period 2001-2017. karakterišu različiti modeli rasta:

- Model rasta baziran na rastu lične potrošnje i usluga 2001-2008. U periodu do izbijanja Svetske ekonomske krize, privredni rast RS je rastao po visokoj prosečnoj stopi $(5,9 \%)$, što međutim, nije bilo dovoljno da se nadoknadi veliki zaostatak iz perioda sankcija i privrednih problema u kojima se nalazila država krajem XX-og veka. Modelu privrednog rasta je najviše doprineo sektor usluga. U strukturi bruto domaćeg proizvoda (BDP), usluge su dostigle 60\%. Nivo BDP RS je 2008. dostigao nivo iz 1975.

- Recesioni period od 2009-2014, period bez rasta, prosečan godišnji pad $-0,2 \%$. Pod uticajem globalne recesije privredni rast je prekinut 2009, i naterao kreatore ekonomske politike da, suočeni sa multisektorskim negativnim efektima globalne recesije, redizajniraju model rasta i tragaju za novim izvorima rasta (Slika 2).

- Novi model rasta baziran na investicijama i izvozu 2015-2017, prosečan godišnji rast 1,8\%. Privredni rast je tek 2016. dostigao predkrizni nivo iz 2008. Na kraju 2017, nivo BDP bio je na nivou 1977, što govori o razmerama ekonomske distorzije $u$ poslednjoj deceniji XX-og veka. 


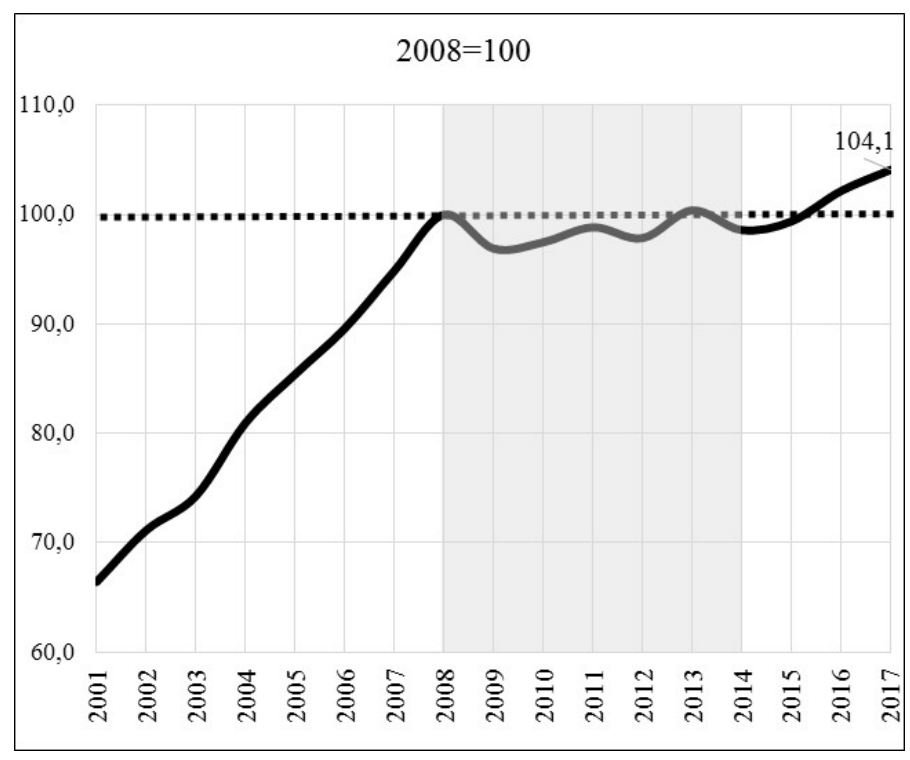

Slika 2 Uticaj krize na privredni rast Republike Srbije, BDP 2008=100

Izvor: Autor, na osnovu podataka RZS

Doslednim sprovođenjem fiskalne konsolidacije u periodu 2015-2017, unutrašnje i spoljne makroekonomske neravnoteže su smanjene, započeto je strukturno prilagođavanje, poboljšan je privredni $\mathrm{i}$ investicioni ambijent, što su potvrdile i renomirane međunarodne institucije (WB, IMF, EBRD, WEF).

Komparativna analiza trendova privrednog rasta $\mathrm{u}$ tranzicionim državama JIE pokazuje različit uticaj ekonomske recesije od države do države. Neke ekonomije uspele su ranije da prevaziđu negativne krizne udare na svoje privrede, zahvaljujući, prvenstveno, otpornosti svojih prerađivačkih sektora (Tabela 1).

U predkriznom periodu, 2001-2008, dinamika privrednih aktivnosti RS bila je iznad proseka zemalja iz okruženja. U periodu 2009-2016, najviši rast BDP-a zabeležile su Albanija i Makedonija, dok je najveći pad zabeležen u Hrvatskoj (Tabela 1). U većini zemalja regiona, dominantan uticaj na privredni rast je imala domaća tražnja (investicije i privatna potrošnja). Samo je u Bugarskoj neto izvoz imao veći doprinos od domaće tražnje.
Tabela 1 Privredni rast u tranzicionim državama regiona

\begin{tabular}{|c|c|c|c|c|}
\hline \multirow{2}{*}{ Država } & \multicolumn{2}{|c|}{$\begin{array}{c}\text { Stopa rasta/pada } \\
\text { BDP }\end{array}$} & \multicolumn{2}{|c|}{$\begin{array}{l}\text { BDP per capita } \\
2016 .\end{array}$} \\
\hline & $\begin{array}{l}2001- \\
2008\end{array}$ & $\begin{array}{c}2009- \\
2016\end{array}$ & EUR & $\begin{array}{l}\text { PPS EU- } \\
28=100\end{array}$ \\
\hline Albanija & 6,0 & 2,4 & 3.700 & 30 \\
\hline $\begin{array}{l}\text { Bosna i } \\
\text { Hercegovina }\end{array}$ & 4,9 & 0,9 & 4.400 & 31 \\
\hline Bugarska & 5,8 & 1,1 & 6.748 & 48 \\
\hline BJR Makedonija & 3,0 & 2,2 & 4.691 & 38 \\
\hline Rumunija & 6,3 & 1,1 & 8.640 & 59 \\
\hline Republika Srbija & 5,9 & 0,3 & 4.904 & 36 \\
\hline Hrvatska & 4,3 & $-1,1$ & 11.142 & 59 \\
\hline Crna Gora & 5,0 & 1,1 & 6.354 & 42 \\
\hline Slovenija & 4,2 & $-0,3$ & 19.574 & 83 \\
\hline Mađarska & 3,2 & 0,6 & 11.588 & 67 \\
\hline
\end{tabular}

Izvor: Eurostat, RZS 
Efekti tranzicije su se, pre svega, odrazili na životni standard u ovim državama. Životni standard u RS u 2016. (BDP per capita je iznosio 4.904 EUR), bio je viši nego u Albaniji, Makedoniji i Bosni i Hercegovini, ali je bio niži od životnog standarda u Bugarskoj (za 37\%), Rumuniji (za 76\%), Hrvatskoj i Mađarskoj (2,3 puta) i Sloveniji (4 puta). U odnosu na kupovnu moć, RS se nalazi na 36\% proseka EU-28 (BDP po kupovnoj moći), što je znatno ispod razvijenijih tranzicionih država u okruženju (Mađarska zaostaje za prosekom EU 33\%, Hrvatska 41\%, a Slovenija 17\%).

U predkriznom periodu, stopa zaposlenosti u RS se nije menjala, stopa nezaposlenosti je pala na $14,9 \%$, inflacija je smanjena, ali je i dalje bila na visokom nivou, SDI su imale značajan rast, deficit tekućeg računa je bio visok, javni dug se držao pod kontrolom. Uticaj recesije najviše je uticao na povećanje spoljnog duga i na smanjenje investicija (i bruto investicija iSDI). Pozitivni makoroekonomski rezultati u postkriznom periodu su fiskalna konsolidacija (smanjenje fiskalnog deficita) i spuštanje inflacije ispod 3\%.

Analiza transformacionog perioda, 2001-2017, pokazuje stepen neodrživosti modela rasta u periodu
2001-2008, negativne efekte $u$ recesionom periodu 2009-2014, pre svega, rast nezaposlenosti, pad životnog standarda i rast duga, i promenu modela rasta u poslednjih nekoliko godina (Jakopin, 2018, 43). Posledice transformacionog modela ekonomija na dug odrazile su se u svim razvojnim dimenzijama, od demografske regresije, preko industrijske devastacije, obrazovnog jaza, regionalnih neravnomernosti, institucionalne neizgrađenosti.

Zaokret i promenu modela privrednog rasta najplastičnije pokazuje analiza rashodne strukture doprinosa rastu BDP (Slika 3). Predkrizni model rasta, 2001-2008, se bazirao, skoro isključivo, na rastu lične potrošnje, što je, donekle, i razumljivo imajući $\mathrm{u}$ vidu posledice ekonomske distorzije na životni standard stanovništva u poslednjoj deceniji prošlog veka. Doprinos lične potrošnje rastu je konstantno bio oko 5\%, dok je, npr. u 2008. iznosio čak $8 \%$. Spoljnotrgovinski deficit je permanentan, doprinos investicija privrednom rastu uglavnom se odvijao kroz proces privatizacije. Državna potrošnja je, takođe, do 2009. doprinosila rastu.

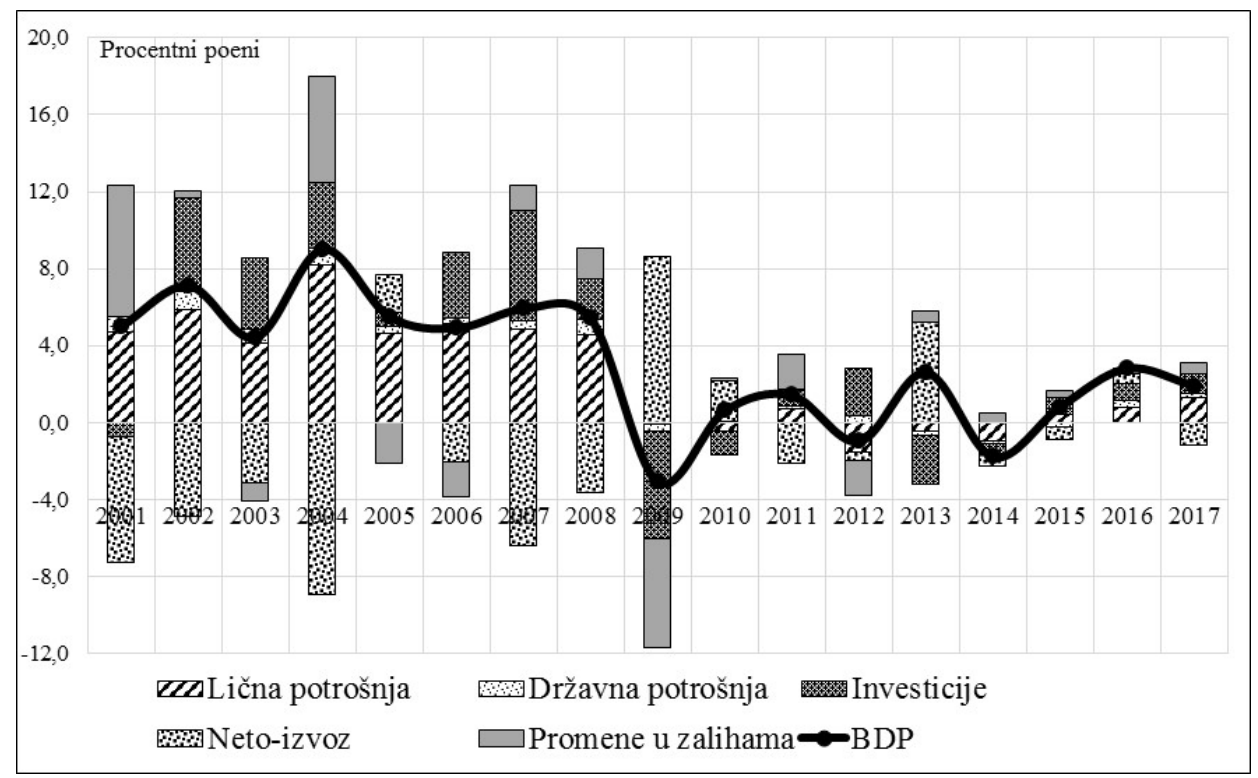

Slika 3 Modeli rasta - struktura doprinosa rastu BDP u Republici Srbiji 
U periodu recesije došlo je do drastičnog pada lične potrošnje i investicija, dok je recesionom padu značajno doprineo i spoljnotrgovinski deficit. U 2015, po prvi put je registrovan pozitivan doprinos investicija, koji je nastavljen u 2016. i u 2017. Od modela rasta zasnovanog na rastu potrošnje, privreda se, posle pet recesionih godina, 2015. polako usmerava ka modelu rasta zasnovanog na investicijama i, posle dužeg perioda, na ličnoj potrošnji. Doprinos lične potrošnje ima uzlazni trend. Njen doprinos rastu u 2015. iznosio je 0,4\%, u 2016, 0,7\%, i u 2017. 1,3\%.

\section{INSTITUCIONALNA TRANZICIJA}

Teoretičari institucionalne tranzicije sam pojam institucije definišu dosta široko, najčešće to su "formalna i neformalna pravila i mehanizmi njihovog sprovođenja koji oblikuju ponašanje pojedinaca i organizacija u društvu" (Burki \& Perry, 1998). Formalne institucije su zakoni, propisi i ugovori, a neformalne: poverenje, etika i političke norme. Razlikujemo političke institucije (zakonodavne, političke partije, vladine agencije, pravosuđe), ekonomske institucije (privatne firme, sindikate, poslovna udruženja) i socijalne institucije (NVO, škole). Teoretičari institucionalnog rasta koji tvrde da institucije dominiraju politikama, definišu institucije kao

„grupu društvenih aranžmana koji sadrže ustavna i društvena ograničenja zasnovana na moći političara i elita, vladavini zakona, odredbe za posredovanje u društvenim konfliktima, jaku primenu imovinskih prava, minimalni obim jednakih mogućnosti i relativno širok pristup obrazovanju, i sl." (Acemoglu, Johnson, \& Robinson, 2005).

Slično, jedna grupa autora definiše institucije kao „pravila igre u društvu i njihov doprinos za poželjno ekonomsko ponašanje" (Rodrik, Subramanian \& Trebbi, 2004), posebno ističući vladavinu prava i zaštitu imovinskih prava. „Institucije su primarne za vladavinu prava” i „sprovođenje zakona” (Dollar \& Kraay, 2002).
Teorijski okvir povezanosti institucionalnog razvoja i privrednog rasta je izuzetno raznovrstan. O snažnoj vezi izgradnje institucija i privrednog razvoja značajan doprinos dali su: E. L. Jones (1981), D. North (1990), S. Knack i Ph. Keefer (1995), P. Mauro (1995), W. Easterly i R. Levine (2003), D. Acemoglu, S. Johnson i J. A. Robinson (2005), S. L. Engerman i S. Sokoloff (2010) i dr. Presudan faktor uspešnih tranzicionih rezultata je efikasnost novoosnovanih institucija (Hoff \& Stiglitz, 2004).

Možda jedan od najvećih nedostataka nametnutih reformskih agendi, sa ciljem kako pomoći tranzicionim privredama, predstavlja nedoslednost i selektivnost $u$ jačanju instituta vladavine prava, imovinskih prava i investicione klime (što je sve, manje-više, usko povezano). Definicija Svetske banke insistira na efikasnosti institucija, ne stavlja akcenat na razvoju instituta, recimo, vladavine prava, što je dug i sistemski zahtevan proces sa socijalnim implikacijama.

Reformska agenda institucionalne tranzicije $\mathrm{u}$ fokus stavlja: vladavinu prava, sprovođenje zakona, dostupnost znanju i obrazovanju, političku participaciju, socijalnu jednakost i solidarnost, toleranciju i odgovornost.

$\mathrm{Na}$ teorijskom konceptu da institucionalna tranzicija podrazumeva tri ključna faktora: proces izbora i kontrole vlasti, institucionalno donošenje i implementacija politika i razvoj institucija u službi građanina, autori D. Kaufmann, A. Kraay i M. Mastruzzi (2010) su kreirali kompozitni Indikator efikasnog institucionalnog upravljanja (Worldwide Governance Indicators - WGI), i razvili metodologiju pomoću koje se može pratiti institucionalna tranzicija u tranzicionim državama. Metodologija se sastoji od šest kompozitnih podindeksa (dimenzija):

- Sloboda govora i odgovornost (Voice and Accountability - VA) - pruža informacije u kom stepenu građani mogu učestvovati $u$ izboru njihove vlade, o slobodi izražavanja, slobodi udruživanja i o slobodnim medijima; 
- Politička stabilnost i odsustvo terorizma (Political Stability and Absence of Violence/Terrorism - PV) - daje informacije o verovatnoći da će vlada biti destabilizovana ili srušena, neustavnim ili nasilnim sredstvima, uključujući politički motivisano nasilje i terorizam;

- Efikasnost vlade (Government Effectiveness GE) - obuhvata informacije o kvalitetu javnih usluga, kvalitetu državne službe i stepenu njene nezavisnosti od političkih pritisaka;

- Kvalitet regulative (Regulatory Quality - RQ) - pruža informacije o sposobnosti vlade da formuliše i primeni zdravu politiku i propise koji dozvoljavaju i promovišu razvoj privatnog sektora;

- Vladavina prava (Rule of Law - RL) - daje informacije u kojoj meri institucije imaju poverenje i poštuju pravila društva, naročito kvalitet izvršenja ugovora, poštovanje imovinskih prava, rad policije i sudova, kao i procene o mogućem kriminalu i nasilju;

- Kontrola kurupcije (Control of Corruption - CC) - obuhvata informacije o tome koliko se javna vlast koristi za privatnu korist, uključujući i sitne i velike oblike korupcije, kao i stepen zloupotrebe državnih institucija od elita i privatnih interesa.

Metodologija obuhvata nekoliko stotina varijabli iz 31 različitog izvora podataka, sadrži percepcije upravljanja, kao što su izveštaji ispitanika, nevladine organizacije, davaoci komercijalnih informacija o poslovanju i organizacije iz javnog sektora širom sveta. Baze podataka postoje od 1996. za dvesta država sveta. Kompozitni indikator WGI se, preko sistema jednačina, izražava u standardnim normalnim jedinicama (u rasponu od $-2,5$ do 2,5).

Tranzicione ekonomije su napredovale $u$ izgradnji institucija, ali različitom dinamikom, i u različitim periodima. RS je 2000. imala najveći institucionalni jaz $\mathrm{u}$ odnosu na ostale tranzicione države (WGI -1,07). U periodu 2001-2008 države JIE značajno su ojačale svoje nove institucije, da bi u periodu recesije process jačanja institucija kod većine tranzicionih ekonomija bio zaustaviljen (Tabela 2). U Bugarskoj,
Mađarskoj i Sloveniji recesija i pad privrednog rasta uticali su na razgradnju institucija. Institucije su najslabije u najmanje razvijenim državama - Albaniji, Bosni i Hercegovini i Moldaviji (WGI ima negativnu vrednost).

Tabela 2 Merenje institucionalnog napretka

\begin{tabular}{l|cccc}
\hline \multirow{2}{*}{ Država } & \multicolumn{4}{|c}{ WGI-prosek } \\
& 2000 & 2008 & 2009 & 2016 \\
\hline Albanija & $-0,62$ & $-0,21$ & $-0,16$ & $-0,02$ \\
BiH & $-0,52$ & $-0,34$ & $-0,37$ & $-0,32$ \\
Bugarska & 0,13 & 0,20 & 0,25 & 0,18 \\
Hrvatska & 0,17 & 0,37 & 0,39 & 0,45 \\
BJR Makedonija & $-0,50$ & $-0,07$ & $-0,05$ & $-0,12$ \\
Moldavija & $-0,42$ & $-0,43$ & $-0,45$ & $-0,41$ \\
Crna Gora & $-0,61$ & 0,09 & 0,15 & 0,07 \\
Rumunija & $-0,18$ & 0,13 & 0,14 & 0,25 \\
Republika Srbija & $-1,07$ & $-0,26$ & $-0,17$ & 0,01 \\
Prosek JIE & $-0,40$ & $-0,06$ & $-0,03$ & 0,01 \\
Slovenija & 0,89 & 1,03 & 1,03 & 0,94 \\
Mađarska & 0,97 & 0,84 & 0,74 & 0,48 \\
Češka Republika & 0,56 & 0,92 & 0,92 & 0,96 \\
\hline
\end{tabular}

Izvor: Autor, na osnovu Worldwide Governance Indicators

Analiza institucionalnih podindeksa WGI pokazuje (Tabela 3):

- Najveća institucionalna slabost i najslabiji tranzicioni institucionalni rezultati na području JIE u 2016. su Vladavina prava (prosek podindeksa RL država JIE -0,11) i Kontrola korupcije (prosek podindeksa CC -0,28).

- Najveći pomak su napravile institucije na polju Političke stabilnosti (podindeks PV je iz ogromne negativne zone $-0,66$, na početku tranzicije 2000, prešao u pozitivnu zonu) i Kvaliteta regulative (podineks RQ je sa -0,32 u 2000. ušao u pozitivnu zonu na $+0,25)$. 
Tabela 3 Institucionalna tranzicija u tranzicionim državama WGI 2000-2016

\begin{tabular}{l|cc|cc|cc|cc|cc|cc}
\hline \multirow{2}{*}{ Država } & \multicolumn{2}{|c|}{ VA } & \multicolumn{2}{c|}{ PV } & \multicolumn{2}{c|}{ GE } & \multicolumn{2}{c|}{ RQ } & \multicolumn{2}{c|}{ RL } & \multicolumn{3}{c}{ CC } \\
\hline Albanija & 2000 & 2016 & 2000 & 2016 & 2000 & 2016 & 2000 & 2016 & 2000 & 2016 & 2000 & 2016 \\
Bosna i Hercegovina & $-0,29$ & 0,16 & $-0,54$ & 0,26 & $-0,76$ & 0,00 & $-0,25$ & 0,20 & $-1,01$ & $-0,35$ & $-0,86$ & $-0,40$ \\
Bugarska & $-0,11$ & $-0,16$ & $-0,53$ & $-0,38$ & $-0,84$ & $-0,43$ & $-0,50$ & $-0,18$ & $-0,61$ & $-0,29$ & $-0,56$ & $-0,47$ \\
Hrvatska & 0,46 & 0,44 & 0,38 & 0,03 & 0,00 & 0,29 & 0,20 & 0,55 & $-0,12$ & $-0,04$ & $-0,13$ & $-0,16$ \\
BJR Makedonija & 0,51 & 0,52 & 0,28 & 0,68 & 0,33 & 0,49 & $-0,03$ & 0,36 & 0,03 & 0,44 & $-0,07$ & 0,19 \\
Moldavija & $-0,34$ & $-0,23$ & $-0,62$ & $-0,38$ & $-0,75$ & 0,09 & $-0,13$ & 0,45 & $-0,57$ & $-0,31$ & $-0,60$ & $-0,31$ \\
Crna Gora & $-0,14$ & $-0,03$ & $-0,43$ & $-0,28$ & $-0,51$ & $-0,62$ & $-0,29$ & $-0,05$ & $-0,48$ & $-0,54$ & $-0,66$ & $-0,96$ \\
Rumunija & $-0,50$ & 0,08 & $-1,64$ & 0,16 & $-0,85$ & 0,10 & $-0,86$ & 0,23 & 0,34 & $-0,04$ & $-0,17$ & $-0,10$ \\
Republika Srbija & 0,47 & 0,51 & $-0,38$ & 0,27 & $-0,37$ & $-0,17$ & $-0,11$ & 0,59 & $-0,20$ & 0,30 & $-0,49$ & 0,00 \\
JIE & $-0,64$ & 0,21 & $-1,64$ & 0,05 & $-0,85$ & 0,09 & $-0,86$ & 0,14 & $-1,27$ & $-0,12$ & $-1,18$ & $-0,31$ \\
Slovenija & $-0,06$ & 0,17 & $-0,57$ & 0,04 & $-0,51$ & $-0,02$ & $-0,31$ & 0,25 & $-0,43$ & $-0,11$ & $-0,52$ & $-0,28$ \\
Mađarska & 1,11 & 1,00 & 0,89 & 0,99 & 0,75 & 1,12 & 0,69 & 0,62 & 1,04 & 1,08 & 0,88 & 0,80 \\
Češka Republika & 1,14 & 0,37 & 0,92 & 0,71 & 0,98 & 0,45 & 1,09 & 0,77 & 0,91 & 0,51 & 0,79 & 0,08 \\
\hline
\end{tabular}

Izvor: Worldwide Governance Indicators

- Efekti globalne recesije najviše su se negativno odrazili na podindeks Sloboda govora i odgovornost (VA), ne samo da nije bilo napretka u periodu 2008-2016. nego se prosek podindeksa VA pogoršao (u Mađarskoj pad -0,60 indeksnih poena, Makedonoji -0,43, Bugarskoj -0,14, u Crnoj Gori $-0,16$, u RS -0,07). Interesantno je da je postkrizni pad registrovan $u$ i uspešnim tranzicionim državama, Mađarskoj i Sloveniji. Institut Politička stabilnost, u istom periodu, beleži neznatno poboljšanje (sa 0,02 na 0,04 ), ali u tri razvijenije države registrovan je pad.

- Bosna i Hercegovina i Moldavija su institucionalno ekstremno neefikasne. Njihovi svi podindeksi se nalaze u negativnoj zoni, tako da te dve države (uz Albaniju u podindeksima RL i CC) umnogome kvare prosek celog područja JIE.

- Institut Efikasnost vlade poboljšan je u periodu 2014-2016. u Albaniji, Bugarskoj i RS.

- Pad Kvaliteta regulative (RQ) u postkriznom periodu posebno se odrazio u tranzicionim državama EU u Češkoj Republici (sa 1,15 na 1,08), Mađarskoj (sa 1,19 na 0,77), Hrvatskoj (sa 0,51 na
0,36), Bugarskoj (sa 0,69 na 0,55) i Sloveniji (sa 0,83 na 0,62 ), što je primoralo vlade tih država da mnogo veću pažnju usmere ka institucionalnoj regulativi privatnog sektora.

Institucionalna tranzicija u RS, u tranzicionom periodu 2000-2016, odvijala se različitom dinamikom $\mathrm{i}$ intenzitetom (Slika 4):

- na početku institucionalne tranzicije svi institucionalni podindeksi imali su maksimalne negativne vrednosti: Politička stabilnost na rekordnom minimumu (PV -1,64), Kontrola korupcije (CC -1,18), Kvalitet regulative (RQ -0,86), Efikasnost vlade (GE -0,85), Sloboda govora (VA $-0,64)$ i Vladavina prava (RL -1,27);

- u predkriznom periodu, do 2008, najveći institucionalni pomaci postignuti su $u$ podindeksima Sloboda govora (VA 0,28), Efikasnost vlade (GE -0,19) i Kontrola korupcije (CC -0,31);

- u kriznom periodu, 2009-2013, došlo je, uz neznatne oscilacije, ili do pogoršanja, ili do stagnacije svih podindeksa WGI; 


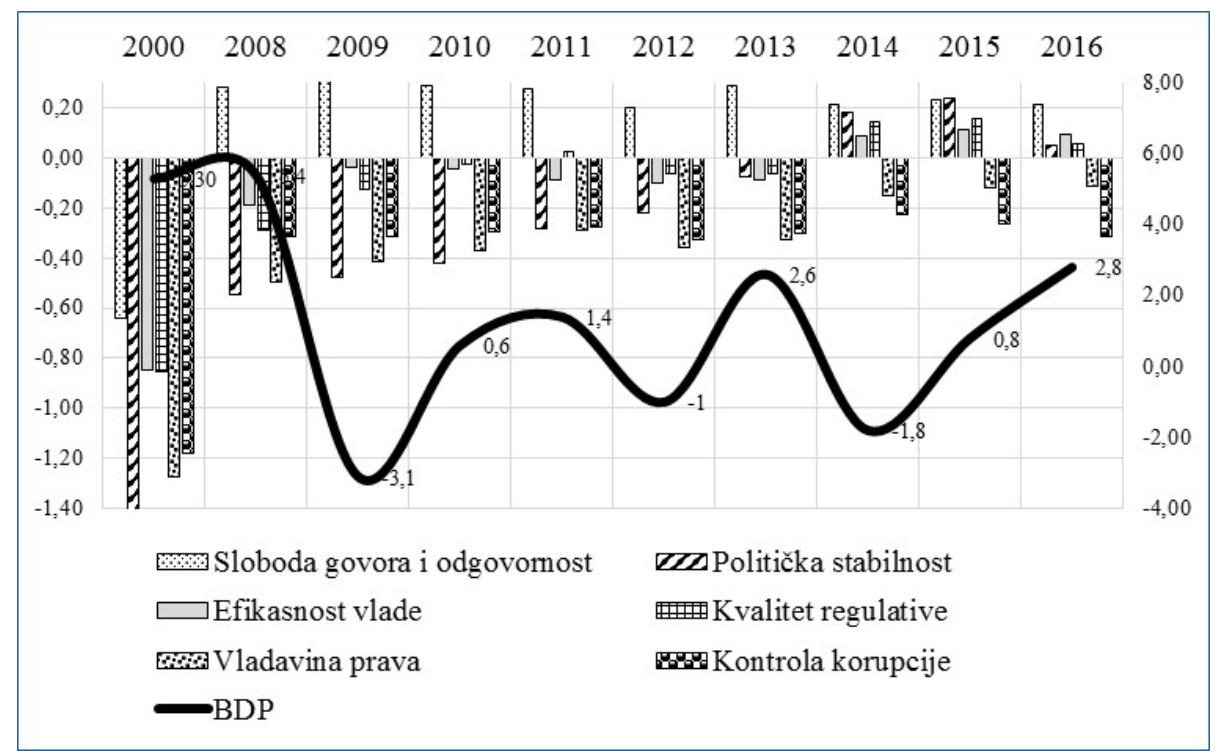

Slika 4 Efekti krize na institucionalnu tranziciju i privredni rast u Republici Srbiji

Izvor: Autor, na osnovu baza podataka Svetske banke (WGI) i RZS

- u periodu 2014-2016, poboljšani su i nalaze se u pozitivnoj zoni podindeksi: Politička stabilnost (PV), Efikasnost vlade (GE) i Kvalitet regulative (RQ);

- najkritičniji institucionalni pokazatelj za RS je konstantno Kontrola korupcije (CC) i Vladavina prava (RL), ali se po Kvalitetu regulative (RQ) nalazi ispod proseka JIE;

- RS za uspešnim tranzicionim državama najviše zaostaje u pokazateljima Vladavina prava (RL), Efikasnost vlade (GE), Kvalitet regulative (RQ).

\section{KORUPCIJA KAO FAKTOR RAZGRADNJE INSTITUCIJA}

Institucionalna neizgrađenost je jedan od ključnih faktora rasta korupcije u nerazvijenim ekonomijama u kojima su tržišne institucije još u razvoju. Teško je odmotati začaran krug birokratske neefikasnosti i rasta korupcije, šta je uzrok, a šta posledica. Matrica faktora korupcije (pozitivnih i negativnih) prikazana je u Tabeli 4.
Empirijski je dokazan uticaj neizgrađenih institucija na poslovnu investicionu klimu, utvrđeno je da visoki nivoi korupcije smanjuju privredni rast zemlje, investicionu klimu i kvalitet investicije. Efekti korupcije razaraju institucije i privredni rast, uzrokuju neefikasnu alokaciju sredstava, smanjuju produktivnost. Posebno je negativan efekat stepena korupcije na privlačenje SDI. Proces investiranja, po pravilu, obuhvata, dobijanje pregršt javnih dozvola, što može zahtevati oblik mita, čime se povećavaju troškovi investiranja i smanjuje ukupan priliv SDI (Saha, Rukmani \& Jen-Je, 2009).

Korupcija povećava nejednakost dohotka (rast Ginijevog koeficijenta) i siromaštvo kroz smanjenje nivoa rasta, poreski sistem, socijalne programe lošeg kvaliteta, nejednakost u obrazovanju i pristrasnost vlasništva nad sredstvima (Tanzi, 1998). Efekat sa kojim su suočene ekonomije $\mathrm{u}$ tranziciji je rast sive ekonomije. Skoro sve tranzicione države u cilju borbe protiv sive ekonomije donele su strateška dokumenta i akcione planove. U periodu 2012-2017. Vlada Republike Srbije je smanjila obim sive ekonomije, sa $21,2 \%$ na $15,4 \%$, ali i dalje u brojnim institucionalnim 
Tabela 4 Matrica faktora korupcije

\begin{tabular}{|c|c|}
\hline + (povećanje korupcije) & -(smanjenje korupcije) \\
\hline $\begin{array}{l}\text { Birokratija i neefikasna administrativna i politička } \\
\text { struktura } \\
\text { (Tanzi, 1998, Goel i Nelson, 2010) }\end{array}$ & $\begin{array}{l}\text { Učešće građana/sloboda štampe } \\
\text { (Bhattacharyya i Hodler, 2010) }\end{array}$ \\
\hline $\begin{array}{l}\text { Slabe institucije } \\
\text { (Pellegrini i Gerlagh, 2007) }\end{array}$ & $\begin{array}{l}\text { Privredni rast, investicije } \\
\text { (Pellegrini i Gerlagh, 2007) }\end{array}$ \\
\hline $\begin{array}{l}\text { "Resursno prokletstvo" } \\
\text { (Bhattacharyya i Hodler, 2010) }\end{array}$ & $\begin{array}{l}\text { Viši nivo ekonomske slobode, slobode izbora, manje } \\
\text { ekonomskih kontrola } \\
\text { (Saha, Gounder i Su, 2009) }\end{array}$ \\
\hline $\begin{array}{l}\text { Politička nestabilnost } \\
\text { (Goel i Nelson, 2010) }\end{array}$ & $\begin{array}{l}\text { Globalizacija } \\
\text { (Charron, 2009) }\end{array}$ \\
\hline $\begin{array}{l}\text { Siromaštvo } \\
\text { (Tanzi, 1998, Goel i Nelson, 2010) }\end{array}$ & $\begin{array}{l}\text { Decentralizacija } \\
\text { (Dell'Anno i Teobaldelli, 2015) }\end{array}$ \\
\hline $\begin{array}{l}\text { Nizak nivo zaštite imovinskih prava } \\
\text { (Pellegrini i Gerlagh, 2007) }\end{array}$ & $\begin{array}{l}\text { Tržište i konkurencija } \\
\text { (Alexeev i Song, 2013) }\end{array}$ \\
\hline $\begin{array}{l}\text { Niske zarade } \\
\text { (Goel i Nelson, 2010) }\end{array}$ & $\begin{array}{l}\text { Trgovinska otvorenost } \\
\text { (Charron, 2009) }\end{array}$ \\
\hline $\begin{array}{l}\text { Efekti okruženja } \\
\text { (Goel i Nelson, 2010) }\end{array}$ & $\begin{array}{l}\text { Transparentnost } \\
\text { (Goel i Nelson, 2010) }\end{array}$ \\
\hline $\begin{array}{l}\text { Niže obrazovanje } \\
\text { (Pellegrini i Gerlagh, 2007) }\end{array}$ & $\begin{array}{l}\text { eGovernment } \\
\text { (Elbahnasawy, 2014) }\end{array}$ \\
\hline $\begin{array}{l}\text { Imigracija iz visoko korumpirane zemlje } \\
\text { (Dimant, Krieger i Meierrieks, 2013) }\end{array}$ & $\begin{array}{l}\text { Internet } \\
\text { (Goel i Nelson, 2010) }\end{array}$ \\
\hline
\end{tabular}

Izvor: Autor, na osnovu citiranih radova

segmentima postoji značajan prostor za povećanje efikasnosti borbe protiv sive ekonomije.

Sprega institucionalne neizgrađenosti i korupcije posebno pogađa tranzicione države kroz „odliv mozgova" i kvalitet ljudskog kapitala. Empirijski je utvrđeno da visoki nivoi korupcije utiču na nivo emigracije kvalifikovane radne snage daleko više od nekvalifikovane radne snage (Dimant, Krieger \& Meierrieks, 2013). Viši nivoi korupcije su povezani sa nižim nivoima obrazovanja, zdravstva, socioekonomskog razvoja, što utiče na smanjenje nivoa ljudskog kapitala.

\section{ZAKLJUČAK}

Nalazimo se $\mathrm{u}$ vrtlogu globalnih ekonomskih promena. Osnovne karakteristike tih promena su:

- neoliberalni globalizam doprinosi sve većoj socijalnoj polarizaciji;

- progresivno se povećava marginalizacija, otuđuje se rad iz proizvodnog procesa, što dovodi do nestajanja socijalnog okvira unutar koga bi dobitak mogao biti društveno podeljen;

- permanentne su promene u poslovnom ciklusu i stvara se klima stalne nadolazeće recesije; i 
- deregulacija globalne trgovine pogoršava strukturne neravnoteže, ne vodi ka strukturalnim prilagođavanjima.

Uticaj tih procesa direktno uzrokuje da se „državne elite angažuju u trci prema donjim konkurentskim strategijama" (Jakopin, 2017b, 115).

U transformacionom periodu dugom skoro tri decenije mogu se među tranzicionim državama primetiti velike razlike $u$ institucionalnom $i$ ekonomskom razvoju. $\mathrm{Na}$ području JIE sve su primetnije ekonomske (stopa i održivost privrednog rasta) $\mathrm{i}$ institucionalne (efikasne i stabilne institucije $u$ funkciji privrednog rasta) razlike između država koje su članice EU i onih koje su kandidati. Na razgradnju, ionako krhkih institucija na području JIE, razorno je delovala globalna recesija (Jakopin, 2018, 51-54). Pored zakasnelog tranzicionog starta (Republika Srbija, Bosna i Hercegovina, Makedonija), na institucionalnu izgradnju uticale su ekonomske politike i strategije reformi.

Uticaj institucija na privredni rast i razvoj je direktan preko efikasnosti države (regulatorna, alokativna, podsticajna funkcija), posebno u kriznim periodima kada dolazi do izražaja nesavršenost tržišta kao sveregulisajućeg instrumenta. Efikasan institucionalni okvir kreira privredni ambijent, stvara instrumente, mehanizme i mere za održiv privredni rast. Države u kojima je na visokom stepenu vladavina prava imaju trostruko veću stopu privrednog rasta. Razloge zašto je područje JIE ekonomska periferija EU treba tražiti, pored zakasnelog tranzicionog starta i političkog nasleđa, pre svega, u tome što institucionalna tranzicija nije uspešno sprovedena.

$\mathrm{Na}$ rezultate istraživanja $\mathrm{u}$ radu, ukazuju sledeći zaključci:

- Primenjeni tranzicioni modeli privrednog rasta nisu bili u funkciji izgradnje stabilnih institucija. Institucionalna izgradnja bila je $u$ senci procesa transformacije vlasničke strukture. Neizgrađenost i neefikasnost institucija direktno je uticala na efekte procesa privatizacije, kao i postprivatizacione efekte, ne samo $u$ RS, nego i u državama u okruženju.
- Tokom čitavog tranzicionog perioda postoji permanentan jaz između reformskih zakona i njihove implementacije. Institucije bez kapaciteta za sprovođenje zakona stvaraju ne samo neusklađenost između proklamovanog i stvarnog, već i podstiču marginalizaciju i nesprovođenje zakona.

- Institucionalnom jazu najviše doprinosi faktor korupcije, koji se "hrani" birokratijom, neefikasnom administracijom, niskim zaradama i siromaštvom.

- Institucije imaju veliki problem otvorenosti, što se ide od centralnog ka lokalnom nivou institucionalna zatvorenost i netransparentnost je sve veća. Istraživanje Centra za demokratsku tranziciju o otvorenosti institucija (vlada, skupština, ministarstva i organi uprave) $u$ državama Crnoj Gori, Republici Srbiji, Bosni i Hercegovini i BJR Makedoniji (oktobardecembar 2016) i dobijeni rezultati na osnovu Regionalnog indeksa otvorenosti ukazuju na veliku institucionalnu zatvorenost, selektivnost i arbitrarnost (npr, organi izvršene vlasti u RS otvoreni su 56\%, Crnoj Gori 66\%, Makedoniji $36 \%$ i $\mathrm{BiH} 44 \%)$. Koncept otvorenih vlada u toku procesa integracija $u$ EU nije u potpunosti zaživeo, nije prepoznata suštinska potreba društva o neophodnosti primene i promocije reformskih vrednosti i njihovog pozitivnog uticaja na građane. $\mathrm{U}$ tom kontekstu, neophodno je kontinuirano sprovoditi istraživanje otvorenosti institucija na svim nivoima vlasti.

Istraživački doprinos kroz testiranje polazne hipoteze o međusobnom uticaju institucionalne tranzicije i privrednog rasta ukazuje da je uticaj institucija na tranzicioni privredni rast u Republici Srbiji bio zanemarljiv, može se govoriti samo o obrnutom uticaju, odnosno, o uticaju privrednog rasta na razvoj institucija. U periodu 2001-2008, kada je prosečna stopa privrednog rasta u RS iznosila 5,9\%, svi pokazatelji institucionane efikasnosti beležili su značajan rast. Nasuprot tome, u recesionom periodu, do 2014, kada faktički nije bilo rasta, u većini pokazatelja institucionane efikasnosti registrovan 
je pad ili stagnacija. Blagi oporavak i rast u periodu 2015-2017 odrazio se na poboljšanje kod jednog broja institucionalnih pokazatelja (politička stabilnost, efikasnost vlade i kvalitet regulative).

Završna poruka kreatorima ekonomske politike glasi: kao što održiv privredni rast nije moguć bez stabilnih i efikasnih institucija, tako ni stabilne i efikasne institucije nisu moguće $u$ recesionim periodima, ili $u$ periodima niskih stopa privrednog rasta.

\section{REFERENCE}

Acemoglu, D., Johnson, S., \& Robinson, J. A. (2005). Institutions as the fundamental cause of long-run growth. In P. Aghion, \& S. Durlauf (Eds.). Handbook of Economic Growth Volume $1 A$ (pp. 385-472). Amsterdam, North Holland: Elsevier B.V. doi:1O.1016/S1574-W84(05)OloW

Alexeev, M., \& Song, Y. (2013). Corruption and product market competition: An empirical investigation. Journal of Development Economics, 103(1), 154-166. doi.org/10.1016/j. jdeveco.2013.02.010

Bhattacharyya, S., \& Hodler, R. (2010). Natural resources, democracy and corruption. European Economic Review, 54(4), 608-621. doi.org/10.1016/j.euroecorev.2009.10.004

Burki, S. J., \& Perry, G. (1998). Beyond the Washington Consensus: Institutions Matter. Washington, DC: World Bank.

Charron, N. (2009). The impact of socio-political integration and press freedom on corruption. The Journal of Development Studies, 45(9), 1472-1493. doi.org/10.1080/00220380902890243

Dell'Anno, R., \& Teobaldelli, D. (2015). Keeping both corruption and the shadow economy in check: The role of decentralization. International Tax and Public Finance, 22(1), 1-40. doi:10.1007/s10797-013-9298-4

Dimant, E., Krieger, T., \& Meierrieks, D. (2013). The effect of corruption on migration 1985-2000. Applied Economics Letters, 20(13), 1270-1274. doi.org/10.1080/13504851.2013.806 776

Dollar, D., \& Kraay, A. (2002). Institutions, trade, and growth. Journal of Monetary Economics, 50(1), 133-162. doi.org/10.1016/ S0304-3932(02)00206-4
Easterly, W., \& Levine, R. (2003). Tropic, germs and crops: How endowments influence economic development. Journal of Monetary Economics, 50(1), 3-39. doi.org/10.1016/ S0304-3932(02)00200-3

Elbahnasawy, N. G. (2014). E-government, internet adoption, and corruption: An empirical investigation. World Development, 57(C), 114-126. doi:10.1016/j. worlddev.2013.12.005

Engerman, S. L., \& Sokoloff, S. (2000). History lessons: Institutions, factor endowments, and paths of development in the new world. Journal of Economic Perspectives, 14(3), 217232. doi:10.1257/jep.14.3.217

Goel,K.R.,\&Nelson, A.M.(2010).Causes of corruption:History, geography and government. Journal of Policy Modeling, 32(4), 433-447. doi.org/10.1016/j.jpolmod.2010.05.004

Hoff, K., \& Stiglitz, E. J. (2004). After the big bang? Obstacles to the emergence of the rule of law in post-communist societies. American Economic Review 94(3), 753-763. doi:10.1257/0002828041464533

Jakopin, E. (2017a). Smart specialisation of manufacturing industry: Relying on one's own strengths and targeted attraction of FDI. Ekonomika preduzeća, 65(1-2), 155-173.

Jakopin, E. (2017b). Privredni rast i institucionalne performanse u tranzicionim državama JIE. Ekonomija danas, Institucije - šta (ne)možemo uraditi bolje, 105-118.

Jakopin, E. 2018. Regionalna tranzicija Srbije. Beograd, Republika Srbija: Zadužbina Andrejević.

Jones, E. L. 1981. The European Miracle: Environments, Economies, and Geopolitics in the History of Europe and Asia. New York, NY: Cambridge University Press.

Kaufmann, D., Kraay, A., \& Mastruzzi, M. (2010). The worldwide governance indicators: Methodology and analytical issues. Working Paper Series 5430, WB.

Knack, S., \& Keefer, Ph. (1995). Institutions and economic performance: Cross-country tests using alternative institutional measures. Economics and Politics, 7(3), 207-227. doi.org/10.1111/j.1468-0343.1995.tb00111.x

Mauro, P. (1995). Corruption and growth. Quarterly Journal of Economics 110(3), 681-712. doi.org/10.2307/2946696

North, D. 1990. Institutions, Institutional Change, and Economic Performance. New York, NY: Cambridge University Press. 
Pellegrini, L., \& Gerlagh, R. (2007). Causes of corruption: A survey of cross-country analyses and extende results. Economics of Governance 9(3), 245-263. doi:10.1007/s10101-0070033-4

Rodrik, D., Subramanian, A., \& Trebbi, F. (2004). Institutions rule: The primacy of institutions over geography and integration in economic development. Journal of Economic Growth, 9(2), 131-165. doi:10.3386/w9305
Saha, S., Rukmani, G., \& Jen-Je, S. (2009). The interaction effect of economic freedom and democracy on corruption: A panel cross-country analysis. Economics Letters, 105(2), 173176.

Tanzi, V. (1998). Corruption around the world: Causes, consequences, scope, and cures. IMF Working Paper No. 98/63, 1-39.

Primljeno 4. aprila 2018, nakon revizije, prihvaćeno za publikovanje 22. avgusta 2018. Elektronska verzija objavljena 27. avgusta 2018.

Edvard A. Jakopin je rukovodilac Odeljenja za strateške analize i industrijsku politiku Ministarstva privrede Republike Srbije. Doktorirao je na Ekonomskom fakultetu Univerziteta u Beogradu. Autor je brojnih naučnih i stručnih radova iz oblasti makroekonomije, planiranja privrednog razvoja, strukturnih promena, konkurentnosti, regionalnog modeliranja.

\title{
ECONOMIC GROWTH AND INSTITUTIONAL TRANSITION OF THE REPUBLIC OF SERBIA
}

\author{
Edvard Jakopin \\ Ministry of Economy, The Republic of Serbia
}

Whether the transitional countries of SEE are trapped in the institutional transition? Institutional transition that lasts almost three decades, in Serbia almost two began a rapid destruction of the institution of the previous political and economic system, but the construction of new market institutions has been slow, inefficient and partial. Serbia lost three decades of economic growth and development, as evidenced by an economic law that it takes twice as much time to restore the system to the previous equilibrium of the length of time in which the system is located off-balance. The average growth in the 17 transition years of $3 \%$ is insufficient to compensate for the enormous backlog of the 1990s. The research contribution to the work focuses on the analysis of the interdependence of economic growth and institution building. A special rakurs is aimed at the corruption factor that destroys institutions in all transition countries, reduces economic growth, productivity and negatively affects the attractiveness of FDI.

Keywords: economic growth, institutional transition, corruption. 